\title{
ESSENCE, the Electronic Surveillance System for the Early Notification of Community-Based Epidemics
}

Howard S. Burkom ${ }^{*}$, Wayne A. Loschen ${ }^{1}$, Richard A. Wojcik ${ }^{1}$, Rekha S. Holtry ${ }^{1}$, Monika A. Punjabi ${ }^{1}$, Martina M. Siwek ${ }^{1}$, Sheri H. Lewis ${ }^{1}$

${ }^{1}$ Johns Hopkins University Applied Physics Laboratory, Laurel, Maryland, United States of America

*Corresponding Author:

Howard.Burkom@jhuapl.edu 
medRxiv preprint doi: https://doi.org/10.1101/2020.08.14.20175398; this version posted August 17, 2020. The copyright holder for this preprint (which was not certified by peer review) is the author/funder, who has granted medRxiv a license to display the preprint in perpetuity.

It is made available under a CC-BY-NC-ND 4.0 International license .

\section{ABSTRACT}

2 The Electronic Surveillance System for the Early Notification of Community-Based Epidemics

3 (ESSENCE) is a secure web-based tool that enables health care practitioners to monitor health

4 indicators of public health importance for detection and tracking of disease outbreaks,

5 consequences of severe weather, and other events of concern. The ESSENCE concept began in an

6 internally funded project at the Johns Hopkins University Applied Physics Laboratory (JHU/APL),

7 advanced with funding from the State of Maryland, and broadened in 1999 as a collaboration with

8 the Walter Reed Army Institute for Research. Versions of the system have been further developed

9 by JHU/APL in multiple military and civilian programs for timely detection and tracking of health

10 threats. Features of ESSENCE include spatial and temporal statistical alerting, custom querying,

11 user-defined alert notifications, geographical mapping, remote data capture, and event

12 communications. These features allow ESSENCE users to gather and organize the resulting wealth

13 of information into a coherent view of population health status and communicate findings among

14 users. The resulting broad utility, applicability and adaptability of this system led to adoption of

15 ESSENCE by the Centers for Disease Control and Prevention (CDC), numerous state and local

16 health departments, and the Department of Defense (DOD) both nationally and globally. With

17 emerging high-consequence communicable diseases and other health conditions, the continued

18 user-requirements-driven enhancements of ESSENCE demonstrate an adaptable disease

19 surveillance capability focused on the everyday needs of public health. The challenge of a live

20 system for widely distributed users with multiple different data sources and high throughput

21 requirements has driven an novel, evolving architecture design.

23 Key Words: biosurveillance; outbreak detection; population health 


\section{INTRODUCTION AND BACKGROUND}

\section{Automated Routine Health Monitoring}

26 Until recent decades, public health disease surveillance relied upon laboratory confirmation and

27 passive participation. Often, the lack of automated detection and reporting resulted in time delays

28 that impeded prompt mitigation activities. Public health institutions thus began using enhanced

29 surveillance techniques with the potential for more timely epidemic detection and tracking. These

30 techniques were incorporated in electronic and increasingly internet-based biosurveillance systems

31 for everyday use by health monitors.

\section{Origin and Early Development}

33 Intensive efforts to establish biosurveillance systems occurred at multiple institutions and

34 government agencies in the late 1990s. The ESSENCE system originated as a collaboration of

35 two such projects. A project of Dr. Michael Lewis, then a medical resident under Dr. Julie Pavlin

36 at the Walter Reed Army Institute for Research, applied US military clinic visit data for outbreak

37 detection in a project called "ESSENCE", Electronic Surveillance System for the Early

38 Notification of Community-based Epidemics (1). Concurrently, JHU/APL was combining civilian

39 data from hospital emergency departments, physician office visits, over-the-counter (OTC) sales,

40 and school absenteeism records, first with internal funding, then for the State of Marylance(2). The

41 two groups joined forces in anticipation of possible bioterrorist activity at the turn of the century

42 as January 1, 2000 approached, and this collaboration along with similar efforts at other

43 institutions led to further funded development in the multi-center Bio-Event Advanced Leading 
medRxiv preprint doi: https://doi.org/10.1101/2020.08.14.20175398; this version posted August 17, 2020. The copyright holder for this preprint (which was not certified by peer review) is the author/funder, who has granted medRxiv a license to display the preprint in perpetuity.

It is made available under a CC-BY-NC-ND 4.0 International license .

44 Indicator Recognition Technology (BIOALIRT) program of 2001-3 for the Defense Advanced

45 Research Project Agency (DARPA) (3) . In leading one of four BIOALIRT research teams, the

46 JHU/APL and WRAIR groups further matured the ESSENCE system concept.

Following the terror attacks of September 11, 2001, ESSENCE was expanded in Maryland, increasingly operationalized in state and local civilian health-monitoring agencies, and implemented in all global US military treatment facilities. Since then, fueled by a succession of initiatives driven by both bioterrorism and natural public health concerns, versions of ESSENCE have been implemented in the Department of Defense (DoD), the Veterans Administration (VA), the Centers for Disease Control and Prevention (CDC), and state and regional public health agencies across the United States and, through collaborative DoD efforts, internationally. Following widespread use of ESSENCE and enhancements at JHU/APL to meet users' evolving needs, the CDC National Syndromic Surveillance Program adopted ESSENCE in 2014 as the standard analytic surveillance and visualization engine on the BioSense platform for state and local public health monitors $(4,5)$. User benefits of ESSENCE have long surpassed the "Early Notification" part of as severe weather, environmental hazards, and substance abuse, and rumor control to enable improved public health response. 


\section{ESSENCE History Highlights}

1997: Early research in hospital information management led to a request by Maryland's Secretary of Health to work with the Maryland Department of Health and Mental Hygiene to develop an automated system to detect bioterrorist attacks.

1999: The precursor to the current ESSENCE system, the Maryland Disease Surveillance and Reporting System (MDSRS), was implemented to monitor for bioterrorism.

Subsequent collaboration with the Department of Defense Global Emerging Infection System led to DARPA's multi-center BIOALIRT program enabling improvements in algorithmic detection and biosurveillance system architectures.

2001: ESSENCE moved from a dynamic web framework to the static pre-built visualizations to exploit commercial GIS technologies. Limitations on user capabilities forced a rapid return to the dynamic web framework with a database backend for ESSENCE II.

Soon after the terrorist attacks of September 11, ESSENCE II was transformed from a limiteduse research project to a live operational civilian surveillance system in Maryland and for all global US military treatment facilities.

2003: In response to the need to monitor the health of deployed US troops in the Iraq War, ESSENCE III was developed and deployed in March 2003. This version featured novel data sources, customizable syndrome groupings, and the first incorporation of external detection algorithms. The ability to implement external analytic methods prompted and validated the addition of an Application Program Interface (API) to the analytics architecture. 
89 2003: Global emergence of the Severe Acute Respiratory Syndrome (SARS) spurred the need to

90 sharpen and narrow case definitions in place of general syndromes. This threat solidified the

91 decision to include free-text chief complaint queries along with diagnosis codes in the

92 aggregations of monitored counts and rates. Tracking of SARS highlighted the power of

93 automated systems for situational awareness, a broader and far more frequently useful

94 objective than novel event detection. Subsequent experience began the expansion of syndromic

95 surveillance from monitoring broad infectious syndrome groups to ad hoc categories of greater

96 clinical specificity and a broader variety of population health threats.

98 2004: Expansion: the DoD Joint Services Installation Pilot Project (JSIPP) and the Department of

99 Homeland Security (DHS) BioWatch program proliferated ESSENCE instances across the US.

100 The influx of new users and widespread user sentiment that shareable and explainable results

101 are no less challenging and important than event detection drove enhancements in visualization

102 flexibility and exportability.

103

104 2004: The states of Maryland and Virginia and the District of Columbia agreed to share data across 105 state lines, and the "Aggregated National Capital Region" (ANCR) version of ESSENCE was

106 created. The Enhanced Surveillance Operating Group (ESOG) of ANCR users was formed to 107 help guide ESSENCE development. The close tie between users and developers became a 108 foundation for future ESSENCE enhancements. 
medRxiv preprint doi: https://doi.org/10.1101/2020.08.14.20175398; this version posted August 17, 2020. The copyright holder for this preprint (which was not certified by peer review) is the author/funder, who has granted medRxiv a license to display the preprint in perpetuity.

It is made available under a CC-BY-NC-ND 4.0 International license .

2006: Expanded usage of ESSENCE including patient data from hundreds of hospitals at the Florida Department of Health led to additions to analytics including "time of arrival" monitoring in which anomalous groups of emergency department (ED) arrivals at hourly intervals were detected and reported with adjustments for patient volume, time of day, and subsyndrome type.

2007: The high-profile mass gathering events of the Super Bowl and the 2009 Presidential Inauguration impelled testing of information-sharing, distinct from data-sharing, strategies including an InfoShare tool to enable timely sharing by ANCR users with national level authorities. This effort foreshadowed multiple events or threats in which local restrictions prevented ESSENCE user sites from sharing explicit data, but derived reports, aggregates, data-free query language, or just descriptions could be legally shared. Implementation of ESSENCE features to facilitate such sharing has continued since then.

2009: Collaboration of the ESSENCE team with DoD-GEIS clarified the need to transition the technology and lessons learned from ESSENCE to an open source version that would be easy to operate, cost-free, and deployable around the world. The Suite for Automated Global Electronic bioSurveillance (SAGES) toolkit was developed, including OpenESSENCE and ESSENCE Desktop editions. While based on the features and functionality of ESSENCE, tools within SAGES were developed specifically for use in low- and middle-income countries. Working with the Veterans Affairs and DoD, the ESSENCE team investigated the benefits and obstacles of including elements of electronic medical records beyond the demographics and 
medRxiv preprint doi: https://doi.org/10.1101/2020.08.14.20175398; this version posted August 17, 2020. The copyright holder for this preprint (which was not certified by peer review) is the author/funder, who has granted medRxiv a license to display the preprint in perpetuity.

It is made available under a CC-BY-NC-ND 4.0 International license .

chief complaints. Working with multi-terabyte database sites prepared ESSENCE developers to deal with large datasets in every jurisdiction.

135 2013: The Boston Marathon bombings led to ESSENCE application to monitor non-infectious 136 health categories including Anxiety, Depression, Suicidal Tendencies and Hearing Loss. 137 These additions helped track the health of the Boston communities in the aftermath of the 138 attacks.

2014: CDC announced the transition of the National Syndromic Surveillance Program (NSSP) to ESSENCE for syndromic systems analytics, to be hosted on the cloud-based BioSense Platform.

144 2016: Non-syndromic alerting algorithms were added to ESSENCE for rare, nonmedical, or 145 uncommonly frequent terms in hospital free-text chief complaints.

147 2017: The opioid overdose crisis led to new, sustained partnerships between ESSENCE users and 148 other public health divisions, such as injury prevention, behavioral health, and drug abuse. 149 Analytic methods were explored to combine multiple data types for improved situational 150 awareness. The MyESSENCE feature was added to allow users to customize dashboards for $151 \quad$ concise daily monitoring.

153 2018: The NSSP Syndrome Definition Committee users began sharing combined free-text and 154 diagnosis code-based definitions for inclusion in local ESSENCE sites. Advanced natural 
medRxiv preprint doi: https://doi.org/10.1101/2020.08.14.20175398; this version posted August 17, 2020. The copyright holder for this preprint (which was not certified by peer review) is the author/funder, who has granted medRxiv a license to display the preprint in perpetuity.

It is made available under a CC-BY-NC-ND 4.0 International license .

language processing methods such as word embeddings were developed and shared among $\mathrm{CDC}$ and local users

2019: Nationwide monitoring of outbreaks of lung injuries associated with the use of vaping products increased demand for and development of system features to assess current data quality, including availability and informative content of the records underlying ESSENCE data displays.

2020: Collaboration among NSSP ESSENCE user groups intensified with evolution and sharing of queries related to COVID-19 pandemic surveillance.

\section{SYSTEM DESCRIPTION AND PRINCIPAL FEATURES}

\section{System Overview}

ESSENCE is an enhanced health surveillance system using advanced mathematical/visual analytics which can detect anomalies in both traditional and non-traditional public health data, with the goal of enabling public health to find and monitor outbreaks of health events and make decisions. Users of ESSENCE access a secure web-based tool to conduct disease surveillance for the purpose of timely detection, situational awareness, and descriptive epidemiologic analysis of baseline disease patterns and outbreaks. For effective public health response, public health authorities must have the ability to identify the infected population so further spread can be contained. Leveraging the near real-time availability of an increasing number of data sources, ESSENCE analytical and alerting capabilities provide an opportunity for public health users to 
medRxiv preprint doi: https://doi.org/10.1101/2020.08.14.20175398; this version posted August 17, 2020. The copyright holder for this preprint (which was not certified by peer review) is the author/funder, who has granted medRxiv a license to display the preprint in perpetuity.

It is made available under a CC-BY-NC-ND 4.0 International license .

176 capture the early stages of an outbreak and track its progress. ESSENCE enables integration of

177 electronic data from both clinical and nonclinical sources to enhance situational awareness. For

178 most users, the primary clinical data source is hospital emergency department chief complaint

179 records. Additionally, based on availability, public health agencies incorporate other data types

180 such as over-the-counter medication sales, poison control call center data, prescription drug data,

181 reportable disease data, vital statistics mortality data, and school absentee data. Once raw data

182 reach ESSENCE, the analysis, visualization, and communication features of ESSENCE allow the

183 end user to gather and organize the resulting wealth of information into a coherent view of

184 population health status and to communicate findings among other users and stakeholders.

186 As a result of ongoing user feedback daily and event-based disease surveillance needs, ESSENCE

187 features include spatial and temporal statistical alerting, custom querying, user-defined alert

188 notifications, geographical mapping, remote data capture, and event communications.

\section{Main Functions}

190 ESSENCE provides three main functions:

191 1) Data ingestion/preprocessing. Traditional and non-traditional data sources are 192 electronically received by ESSENCE and many are mapped to syndrome groupings.

193 During the ingestion process, data are cleansed (e.g. duplicate records removed, invalid characters removed, etc.), updated (e.g. existing records information is updated with new information) and categorized (e.g. syndrome and subsyndrome categorization assigned to records). 
medRxiv preprint doi: https://doi.org/10.1101/2020.08.14.20175398; this version posted August 17, 2020. The copyright holder for this preprint (which was not certified by peer review) is the author/funder, who has granted medRxiv a license to display the preprint in perpetuity.

It is made available under a CC-BY-NC-ND 4.0 International license .

2) Alerting. Multiple temporal and spatial alerting algorithms are applied to each data set to develop a list of alerts or flags for further investigation by public health officials. In addition to algorithms developed by JHU/APL and Walter Reed Army Institute of Research (WRAIR), ESSENCE can incorporate algorithms required by the jurisdiction where the system is deployed.

3) Analysis and Visualization, ESSENCE data and alerts can be analyzed and visualized in multiple ways in the system, both spatially and temporally.

204 Section 4 describes these functions in three subsections: Data Management, Alerting Algorithms, 205 and Visualization.

\section{TECHNICAL DETAILS}

\section{Data Management}

\section{Architecture}

209 The software architecture employed for ESSENCE is a three-tier web application with a

210 presentation layer as a user frontend, a business layer for application of algorithms, and a backend

211 for databases. This architecture runs on modular server configurations, with the number of servers

212 contingent upon the data volume, number of active users, and frequency of required analysis

213 operations. The most common configurations comprise three servers for smaller instances and

214 five servers for larger ones. For systems with larger numbers of data sources and/or data volumes

215 reaching billions of records, the architecture can support additional servers to spread the functional

216 load of the processing. The backend databases are Microsoft SQL Server relational database

217 management systems (RDMS). Database functions include an ingestion database layer that 
medRxiv preprint doi: https://doi.org/10.1101/2020.08.14.20175398; this version posted August 17, 2020. The copyright holder for this preprint (which was not certified by peer review) is the author/funder, who has granted medRxiv a license to display the preprint in perpetuity.

It is made available under a CC-BY-NC-ND 4.0 International license .

218 facilitates extract-transform-load (ETL) operations and performs deduplication and other data 219 cleaning operations. Depending on the user site, the ETL operations are performed by

220 Rhapsody,(6) Mirth,(7) or locally developed scripts to populate the database, and then ESSENCE's

221 Groovy-based data flow management system (8) controls data flow and business logic to transfer

222 data from ingestion to detection to web databases.

223 A detection database layer holds data and manages cube tables for fast algorithm access and 224 execution. Java-coded algorithms access the data and cubes for efficient signal detection on the 225 detection database to separate algorithm processing from user query management. The web 226 database layer expedites rapid formation and display of interactive screens for visualization and 227 communication. Web applications encoded in Java and JavaScript utilize this database via a 228 Tomcat web application server.(9) For display purposes, mapping and other geographic 229 information system (GIS) operations employ the open source tool GeoServer.(10) Users can 230 access the web application through standard web application displays or via a web service API 231 layer for direct access to ESSENCE data and functionality.

\section{Data Types}

233 The types of data analyzed in ESSENCE are the prerogative and responsibility of the jurisdiction,

234 though JHU/APL provides capability for basic types. The ESSENCE system is data agnostic - the

235 only requirement for a monitored data type is the inclusion of a data field. Data time resolution is

236 also unrestricted. Data frequencies in ESSENCE have ranged from seconds to years, though daily

237 data have been most common. All but a few users monitor hospital emergency department (ED)

238 data. Most ESSENCE user jurisdictions face the burden of acquiring their data sources, gaining 239 approval for their routine intended use, and extracting features to monitor. That level of effort 
medRxiv preprint doi: https://doi.org/10.1101/2020.08.14.20175398; this version posted August 17, 2020. The copyright holder for this preprint (which was not certified by peer review) is the author/funder, who has granted medRxiv a license to display the preprint in perpetuity.

It is made available under a CC-BY-NC-ND 4.0 International license.

240 varies greatly by data source. Various users also monitor or have monitored records of the data

241 sources listed below.

242 - over-the-counter remedy sales

243 - physician office visits

244 - laboratory test orders and results

245 - school absenteeism and health office/nurse records

$246 \quad-\quad$ reportable disease cases

247 - poison center call records

$248 \quad$ ASPR DMAT data for disaster response (11)

249 - cardiovascular and other chronic diseases from inpatient encounters

250 - livestock and companion animal health encounters

251 - human vitals measurements

252

- death records

- $\quad$ emergency medical services (EMS) and 911 calls, and

- climate and air quality data

255 Users have also incorporated or adapted data from other surveillance systems such as the National

256 Poison Data System (NPDS).(12) While not all of these sources have proven useful for routine

257 surveillance, users have employed the system to investigate their utility and to seek best data usage

258 practices.

259 In separate studies or projects, individual user jurisdictions or their research partners have also

260 used ESSENCE to analyze records of radiology impressions, genomic sequencing data, zoo animal

261 health, environmental sensor outputs, sales of specific products such as thermometers, orange

262 juice, and tissues, social media posts and searches, and even fantasy sports data. Multiple content 
medRxiv preprint doi: https://doi.org/10.1101/2020.08.14.20175398; this version posted August 17, 2020. The copyright holder for this preprint (which was not certified by peer review) is the author/funder, who has granted medRxiv a license to display the preprint in perpetuity.

It is made available under a CC-BY-NC-ND 4.0 International license .

263 formats used in ESSENCE have included Health Level-7 (HL7) formats for hospital data, National

264 Emergency Medical Services Information System (NEMSIS) formats for EMS data, and others.

265 File formats have included delimited/tabbed/fixed-width American Standard Code for Information

266 Interchange (ASCII) text, extensible markup language (XML) and JavaScript Object Notation

267 (JSON).

268

269

\section{Data Security}

270 All automated data transfers occur over a secure virtual private networks (VPNs), e.g. via secure

271 file transport protocol (SFTP); or over VPN tunnels, e.g. HL7; or by web transfer from a secure

272 website, e.g. NPDS and weather. The use of web application access control allows limited,

273 hierarchical access rights for every user by data source, by fields within a data source (e.g.

274 geography or jurisdiction, syndrome), and by website function (e.g. data details, time series,

275 alerts). These access privileges are customizable in the sense that one user site may control access

276 by health district, others by county or by neighborhood. Some sites build aggregated datasets that

277 meet the monitoring needs of users with limited access rights. Weather and other data sources with

278 no privacy concerns may be made available to all users.

\section{Data Preprocessing and Quality Management}

280 Multiple, data-dependent preprocessing steps include deduplication procedures, formation of

281 syndrome fields, calculation of distances, and deriving additional fields and flags based on 282 jurisdictional business rules and logic. 
medRxiv preprint doi: https://doi.org/10.1101/2020.08.14.20175398; this version posted August 17, 2020. The copyright holder for this preprint (which was not certified by peer review) is the author/funder, who has granted medRxiv a license to display the preprint in perpetuity.

It is made available under a CC-BY-NC-ND 4.0 International license .

284 Procedures for managing data quality issues such as deduplication, temporary dropouts of data

285 feeds, data field value validation, and management of free-text or pick-list entries are incorporated

286 in ESSENCE standard business rules. By these rules, ESSENCE does not update records in place

287 but employs a delete-and-replace approach that has proven faster. For data with the functionality

288 enabled, a history system integrates all prior instances of each record to produce a single master

289 record with the relevant fields for each encounter. An extensive set of reference tables and

290 business logic allows conversion of field entries such as patient age, race, ethnicity, and vitals

291 measurement such as temperature to categorical values from standard sources such as the Public

292 Health Information Network Vocabulary Access and Distribution System (PHIN VADS). A

293 "region" data field is used for general spatial aggregation of patient records and is most often

294 employed to combine count data from collections of zip codes to approximate county-level counts

295 when the county field is unavailable. Beyond these features and conventions, ESSENCE includes

296 a substantial website section with guidance and analysis tools dedicated to helping users manage

297 the quality of their data.

298 Alerting Methods using Statistics and Artificial Intelligence

299 Machine Learning and Natural Language Processing for Trackable Data

300 Features

301 Data sources used or considered for health surveillance include medical encounter billing

302 records, emergency service calls, nurse hotline calls, prescription and over-the-counter remedy

303 sales, absenteeism records, and more recently, social media data such as tweets and web

304 searches. Each data source has its own challenges for user jurisdictions to obtain sustained

305 electronic access from data providers and any requisite government approval. When a data stream 
medRxiv preprint doi: https://doi.org/10.1101/2020.08.14.20175398; this version posted August 17, 2020. The copyright holder for this preprint (which was not certified by peer review) is the author/funder, who has granted medRxiv a license to display the preprint in perpetuity.

It is made available under a CC-BY-NC-ND 4.0 International license .

of any of these sources is acquired for routine monitoring, an immediate question is how to use the

307 streaming data to track health outcomes of concern. An often applied procedure is to track counts

308 of subcategories of the data expected to correspond to these outcomes. These subcategories are

309 commonly called syndromes, generalizing the medical definition of this term denoting disease-

310 related collections of signs and symptoms. Thus, in the surveillance context a syndrome may refer

311 to grouped hospital visits associated with a fixed collection of symptoms, laboratory tests ordered

312 for certain conditions, web searches containing sets of terms, billing records covering any of a

313 class of remedies, or other subgroups depending on the data source. Syndrome formation is a

314 critical step that may use only a fraction of all streaming data and may produce few or many groups

315 to track. The number and composition of syndromes depends on the richness of the data, the

316 number of outcomes of interest, and the resources of the monitoring institution for investigation

317 and response.

319 Syndromes and subsyndromes used in ESSENCE vary depending on the clinical grouping systems

320 available and the needs of the user site. Early versions of ESSENCE formed syndrome groups

321 using diagnosis codes, which have disadvantages of late assignment and emphasis on billing

322 practice in many medical systems. Examples were Respiratory and Gastrointestinal with

323 subsyndromes such as Asthma. Categorization soon switched to the use of free-text chief

324 complaint (CC) or reason-for-visit data fields. For this categorization, the JHU/APL ESSENCE

325 team developed the Chief Complaint Processor (CCP), a versatile, stand-alone program for

326 weighted keyword-based classification by free-text fields. The CCP is highly configurable, with

327 tables including sets of syndromes and subsyndromes with classification rules allowing complex

328 logic, positive and negative weighting of component terms, abbreviation and spelling rules, and a 
medRxiv preprint doi: https://doi.org/10.1101/2020.08.14.20175398; this version posted August 17, 2020. The copyright holder for this preprint (which was not certified by peer review) is the author/funder, who has granted medRxiv a license to display the preprint in perpetuity.

It is made available under a CC-BY-NC-ND 4.0 International license .

329 list of unmodifiable terms. For example, CCP puts a record with a CC of "NAUSEA" or

330 "VOMITING" in the Gastrointestinal (GI) category. The CCP creates a ChiefComplaintsParsed

331 field for use of classification rules after treatment of abbreviations, some misspellings, and other

332 cleanup.(13) These classifications have enabled additional natural language processing and

333 machine learning initiatives by both ESSENCE developers and users, and findings from these

334 initiatives are shared among users with each emerging health threat.(14-16)

335 As done with diagnosis code-based processing, syndrome groups are tabulated, plotted and

336 monitored each day with statistical alerting algorithms for early potential outbreak indications.

\section{Application Principles for Alerting Algorithms}

338 Individual alerting algorithms implemented in ESSENCE are listed and described in the Supportint

339 Materials file "S1 Technical_Details_of_ESSENCE_Alerting_Algorithms.docx".

340 The following principles were derived with users to guide method selection and to clarify

341 interpretation of results:

343 General considerations:

344 - These methods are not intended to positively identify outbreaks without supporting 345 evidence. Their purpose is to direct the attention of a limited monitoring staff with 346 increasingly complex data streams to data features that merit further investigation. They

347 have also been useful for corroboration of clinical suspicions, rumor control, tracking of 348 known or suspected outbreaks, monitoring of special events and health effects of severe 349 weather, and other locally important aspects of situational awareness. Successful users 
medRxiv preprint doi: https://doi.org/10.1101/2020.08.14.20175398; this version posted August 17, 2020. The copyright holder for this preprint (which was not certified by peer review) is the author/funder, who has granted medRxiv a license to display the preprint in perpetuity.

It is made available under a CC-BY-NC-ND 4.0 International license .

value these methods more for the latter purposes and do not base public health responses solely on algorithm alerts.

- These algorithms are one-sided tests that monitor only for unusually high counts, not low ones. Low counts could result from a critical outbreak situation that prevents data reporting, but there are many more common reasons for low counts (such as unscheduled closings or system problems), so the algorithms do not test for abnormally low counts. driven by system considerations. Users need to monitor many types of data rapidly. External covariates such as climate data or clinic schedules may not be available for prompt analysis. Many methods in the literature, armed with substantial retrospective data of a certain type, depend on analysis of substantial history. Day-to-day users, often with only a ESSENCE methods have been adapted from the literature and engineered to system requirements. small fraction of time available for monitoring, will not wait several minutes for each query. In the absence of data history and data-specific analysis time for each stream,

- If the time series monitored by algorithms represent many combinations of clinical groupings, age groups, and geographic regions, excessive alerting may occur simply because of the number of tests applied. The Summary Alert method was implemented to limit such excessive alerting. This method is based on control of the false discovery rate, i.e. the expected ratio of false alerts to the total alert count, and its statistical implementation 
medRxiv preprint doi: https://doi.org/10.1101/2020.08.14.20175398; this version posted August 17, 2020. The copyright holder for this preprint (which was not certified by peer review) is the author/funder, who has granted medRxiv a license to display the preprint in perpetuity.

It is made available under a CC-BY-NC-ND 4.0 International license .

in ESSENCE is detailed in the Summary Alert section below. Aside from analytic methods to control alerting, default alert lists should be limited to results from those time series of concern to the user, either by system design or by active specification by the user. For example, one method of reducing the default alert list is to restrict algorithms to all-age time series groupings. Depending on the scope of the user's responsibility, the alert list may also be restricted according to both epidemiological interest and the resources available for investigation. For example, a monitor of a national-level system with algorithms applied to many facilities may be interested only in alerts with at least 5-10 cases. In circumstances of heightened concern, these restrictions can be relaxed, or the user can use ESSENCE advanced querying methods to apply algorithms to age groups and/or subsyndromes.

Both standard and user-customizable visualizations are available in ESSENCE. Highly

387 configurable and interactive modes of data stratification and filtering, graphical and tabular

388 customization, user preference management, and sharing features allow users to query data and

389 view geographic representations, time series and data details pages, and reports. The following

390 sections summarize key features. Screenshots of selected novel visualizations are shown below.

\section{Standard Visualizations}

392 Following are the most commonly used ESSENCE visualizations: 
medRxiv preprint doi: https://doi.org/10.1101/2020.08.14.20175398; this version posted August 17, 2020. The copyright holder for this preprint (which was not certified by peer review) is the author/funder, who has granted medRxiv a license to display the preprint in perpetuity.

It is made available under a CC-BY-NC-ND 4.0 International license . 412 interest.

413 Details of the attributes available for selection, stratification, and filtering are: quality factors to improve understanding of data features. representations of query results. the specified region. of the list includes a link to the corresponding Time Series View or Data Details Page.

To facilitate selection of desired data by space, time, subpopulation, and clinical specificity, the Query Portal provides the user with tools for detailed design and management of simple or complex queries for routine or ad hoc monitoring. An online Query Wizard facilitates these resolution (daily, weekly, monthly, quarterly, or yearly), temporal detection algorithm, and the user can define custom filters through configuration files that customize visualizations. Options include Free-Text, Reference List, Number Range, and Dates filters. Examples of query field options for filter creation are age group, geography system, syndrome or medical category of

- Geography System: Data can be viewed in many geography systems such as Region, Zip

- The Time Series View provides a graphical display of the temporal behavior of the data with the ability to stratify by specific parameters, view aggregated counts, and infuse data

- The Data Details Page provides line listings of individual records and pie/bar chart

- The Map View allows the user to view both data and alerts on a geographical display of

- The Alert List provides a view of signals generated by the alerting algorithms. Each row processes as in Fig 1. For the desired analysis, the user chooses the data source, date range, time selections from a variety of component filters depending on the data source. For each data source, Code, Hospital, Region of the Hospital, Military Treatment Facility (MTF), School, or 
Store. Each geography system defines a system for geographically filtering your data. Regions are a generic term that defines the default geographic way to view data. Regions normally map to a set of zip codes that closely resemble a county or health district.

- Medical Grouping System: When viewing the data via the Query Portal, the user has the ability to choose between how the various data are presented. Data may be viewed by many grouping systems, including ESSENCE Syndrome, International Classification of Diseases (ICD) Code, Chief Complaint SubSyndrome, Chief Complaint, OTC Category for records of sales of over-the-counter remedies, or Call Center Guideline, depending on which data source is queried.

- Syndrome Grouping: The syndrome groupings used in the ESSENCE system vary depending on the medical grouping systems used and the needs of the user site. These groupings are used to filter data into medically similar sets. Examples of a syndrome grouping are: Respiratory, Rash, Cough/Cold, Sinus, Asthma, Chest Pain, etc. Each medical grouping system will have a set of syndromes or the ability to perform free text queries. A Syndrome Definitions user interface provides a stepwise mechanism for viewing rules that define a syndrome or subsyndrome. In addition to syndrome categories the user may also query based on a Chief Complaint Discharge Diagnosis (CCDD) field, a concatenation parsed chief complaint and discharge diagnosis. Filtering by CCDD category uses Structured Query Language (SQL) "Where" clauses to select records meeting user criteria. In general, this filtering takes the form of simple keyword matching with inclusion of wildcard matching and negation terms.

- Detector: The ESSENCE tools refer to alerting algorithms as detectors. For temporal alerting methods, users may choose any of the methods described in Section 4.2.1. 
medRxiv preprint doi: https://doi.org/10.1101/2020.08.14.20175398; this version posted August 17, 2020. The copyright holder for this preprint (which was not certified by peer review) is the author/funder, who has granted medRxiv a license to display the preprint in perpetuity.

It is made available under a CC-BY-NC-ND 4.0 International license .

440 For queries involving more complex data selection and free-text logic than the query wizard 441 provides, ESSENCE provides an Advanced Query Tool, shown in Fig 2.

Fig 2: The Advanced Query Tool in ESSENCE

445 Once a user has created a query, an action button is available to indicate the use and disposition of 446 the query. Options include formation of time series and tables. Complex queries can be saved for 447 reuse and for application to other appropriate data sources.

\section{User-Customizable Visualizations}

450 In addition to the standard visualizations, ESSENCE offers additional views and analysis modes.

451 Of these, the most commonly used are myESSENCE and myAlerts.

myESSENCE: The myESSENCE feature on the main ESSENCE menu facilitates creation of

454 multiple customized dashboards of graphs, charts, tables, maps, and alerts. Users may create 455 separate dashboards by using a widget interface to select, drag, and drop widgets. They may share

456 each dashboard with other users by providing a copy to the dashboard or by providing a read-only

457 copy over which they maintain control. Possible choices for the widgets are time series graphs,

458 maps, and listings of data details. Parameters for each view, such as start and stop dates, are

459 modifiable. These views may be arranged in 1-, 2-, or 3-column format. Fig 3 exemplifies the 460 dashboard creation process. 
medRxiv preprint doi: https://doi.org/10.1101/2020.08.14.20175398; this version posted August 17, 2020. The copyright holder for this preprint (which was not certified by peer review) is the author/funder, who has granted medRxiv a license to display the preprint in perpetuity.

It is made available under a CC-BY-NC-ND 4.0 International license .

461 The creating user gives each dashboard a text description and a note that is modifiable by creator

462 or shared user. Once created, each dashboard appears as a separate tab on the myESSENCE

463 webpage.

464 By default, each dashboard applies to data from the geographic regions selected for each graph

465 when added to the dashboard. The creator or sharing users may change the region, and ESSENCE

466 will change all views on the dashboard to reflect data from the new region. Users may revert to

467 the default view by choosing “Original Query”.

\section{Fig 3: Formation of Customized Dashboard Using MyESSENCE Feature}

471 myAlerts: The myAlerts feature enables users to set up automatic notifications of query results

472 reflecting specific subpopulations, algorithms, and conditions. Two types of these notifications

473 are available. Notifications triggered by receipt in ESSENCE of data records that satisfy a query

474 definition are Records of Interest alerts. Notifications triggered by minimum count requirements

475 or by algorithms detecting sets of records returned by a query are Detector alerts. Algorithms

476 specified may be any of the methods described in Section 4. The user may also specify a

477 minimum number of records requirement in addition to an alerting algorithm. Fig 4 shows the

478 web page used to create this customized alerting feature. Alerts that require algorithm results that

479 cross a designated statistical threshold may be restricted to require threshold crossings on $\mathrm{m}$

480 consecutive days, or on $m$ of the last $n$ consecutive days. The user may set up automatic email

481 prompts for each customized alert and may choose automated sharing of selected alerts with

482 other designated ESSENCE users. 
medRxiv preprint doi: https://doi.org/10.1101/2020.08.14.20175398; this version posted August 17, 2020. The copyright holder for this preprint (which was not certified by peer review) is the author/funder, who has granted medRxiv a license to display the preprint in perpetuity.

It is made available under a CC-BY-NC-ND 4.0 International license .

483 Developers of ESSENCE have also created single-purpose views and tools for specific

484 jurisdiction needs, including statistics tables and side-by-side graphs, as broadly applicable as

485 possible to all data sources.

486

487

Fig 4: Creation of MyAlert for Customized Anomaly Detection

USER APPLICATIONS AND SUCCESSES

489 This section describes ESSENCE applications in health departments for analysis of a wide range

490 of public health threats in monitored populations.

491 Infectious disease applications

492 Early applications of ESSENCE focused on detection of infectious disease outbreaks, with much

493 attention on influenza-like illness (ILI) because ILI is a prodrome for multiple naturally occurring

494 diseases and for many potentially weaponized for bioterrorism $(35,36)$. Civilian (37), military

495 (36), and VA (38) ESSENCE users monitored for outbreaks of seasonal and nonseasonal outbreaks

496 of febrile respiratory infections, GI infections caused by contaminated food or water, and rarer

497 infections.

498 Surveillance systems were particularly helpful to track the pandemic of novel H1N1 influenza in

4992009 (38). The pandemic was important as an interregional use of surveillance systems to track a

500 common threat. For example, the National Capital Region (NCR) Disease Surveillance Network,

501 comprising ESSENCE users at health departments in the District of Columbia and parts of the

502 states of Maryland and Virginia, shares population-level disease incidence information to promote

503 inter-jurisdictional surveillance. In 2009, this network allowed NCR public health practitioners to 
medRxiv preprint doi: https://doi.org/10.1101/2020.08.14.20175398; this version posted August 17, 2020. The copyright holder for this preprint (which was not certified by peer review) is the author/funder, who has granted medRxiv a license to display the preprint in perpetuity.

It is made available under a CC-BY-NC-ND 4.0 International license .

504 track the course of the pandemic from the spring through the fall, comparing the overall and age505 specific burden of illness to national and neighboring state trends. A broader collaboration of both

506 ESSENCE and non-ESSENCE system users collaborated on a standardized definition of ILI to

507 enable uniform local tracking of the pandemic across the US.(39)

508 Users have applied ESSENCE to form and share queries for indications of other infectious diseases

509 using text from chief complaints, discharge diagnosis, and triage notes when available. Infectious

510 threats tracked in published examples include general waterborne diseases (40), tuberculosis (16),

511 rabies (41), and Middle East Respiratory Syndrome (14). The recent years' concerns over

512 mosquito-borne diseases has also generated new queries by multiple users and occasionally

513 uncovered important cases.(15)

515 The health department of Maricopa County, Arizona presented an example of the benefit of 516 surveillance systems in June, 2018. The department had added an ESSENCE query for signs of 517 Rocky Mountain spotted fever, which is not endemic to that county, because of concerns that cases

518 transferred from endemic areas might be missed. A child's patient record was signaled by the 519 query, and the department contacted the hospital. This contact led to reversal of a medication 520 decision that might have been fatal to the child.(42)

521 Such monitoring activity has repeatedly uncovered unreported cases of diseases for which 522 reporting is mandatory. (43) These findings illustrate the importance of redundancy with systems 523 such as ESSENCE to avoid missing important cases, even when traditional reporting mandates 524 exist. 
medRxiv preprint doi: https://doi.org/10.1101/2020.08.14.20175398; this version posted August 17, 2020. The copyright holder for this preprint (which was not certified by peer review) is the author/funder, who has granted medRxiv a license to display the preprint in perpetuity.

It is made available under a CC-BY-NC-ND 4.0 International license .

525 At submission of this manuscript, intense collaboration of ESSENCE users is focused on tracking

526 of the COVID-19 pandemic. General queries on COVID-like illness and specific ones involving

527 pneumonia and specific symptom sets are being refined and shared.(44)

528 Applications for tracking burden of severe weather, natural disaster

529 events

530 Health departments have used ESSENCE for preparedness, health burden assessment, and

531 response to severe storms and other natural disasters. The state of Oregon conducted a successful

532 program to mitigate the effects of wildfires.(45) This program featured customized ESSENCE

533 queries with other coordinated efforts among state and local health departments and preparedness

534 teams. Among several states that using ESSENCE to monitor the effects of hurricanes, the

535 Tennessee health department devised queries to determine the volume and clustering of patients

536 in local hospitals because of storms in other states.(46) Effective monitoring of some events

537 requires combination of multiple data sources. Following a prolonged storm-related power outage,

538 the health department of Seattle-King County, Washington combined data from ESSENCE

539 emergency department data with ambulance call and public utility data to monitor for cases and

540 clusters of carbon monoxide (CO) poisoning and food poisoning.(47) More recently, the Florida

541 health department monitored for CO poisoning after Hurricane Irma in 2017.(48) Institutions

542 using ESSENCE are increasingly incorporating environmental and other data sources in their

543 systems for richer situational awareness of disaster-related health threats. $(49,50)$ 


\section{Applications for mass gathering surveillance}

546 Scheduled mass gathering events such as political conventions and major athletic competitions

547 concern population health monitors because a) such events are bioterrorism opportunities to affect

548 many victims and gain media attention, b) infections through contaminated food or water could

549 spread rapidly through the expanded population, c) those visiting for several days could import

550 infections or take them back to their own cities, and d) a surge of patients could overwhelm local

551 care provider resources. Adequate preparedness and response require coordination across

552 jurisdiction boundaries, but privacy laws often restrict patient-level data-sharing. ESSENCE

553 syndrome definitions and queries have been customized for many such events. In 2007, Marion

554 County, Indiana and Cook County, Illinois were home counties for the competing teams in Super

555 Bowl XLI, and the game was hosted in Miami-Dade, Florida. Health departments of these

556 geographically distant counties were ESSENCE users, and customization of their systems for the

557 days surrounding the event helped coordinate surveillance despite only two weeks' notice after

558 teams were determined.(51)

559 A partnership of the Florida Department of Health and the U.S. HHS Office of the Assistant

560 Secretary for Preparedness and Response (ASPR) to improve response by Disaster Medical

561 Assistance Teams (DMAT) produced a new ESSENCE module that was deployed for health

562 monitoring of the 2012 Republican National Convention in Tampa.(50) State and county health

563 departments used ESSENCE for coordinated monitoring of crowds at the US Olympic Trials in

564 July 2016.(52) In January 2017, the Washington DC Department of Health used ESSENCE

565 queries along with other data sources for health surveillance at the 58th US presidential

566 inauguration.(53) 
medRxiv preprint doi: https://doi.org/10.1101/2020.08.14.20175398; this version posted August 17, 2020. The copyright holder for this preprint (which was not certified by peer review) is the author/funder, who has granted medRxiv a license to display the preprint in perpetuity.

It is made available under a CC-BY-NC-ND 4.0 International license .

567 For monitoring events outside the US, JHU/APL used the SAGES system in 2014 to monitor the 568 8th Micronesian Games held in Pohnpei Federated States of Micronesia and the 3rd International

569 Conference on Small Island Developing States in Apia, Samoa.(54)

570 Applications for chronic disease and mental health surveillance

571 Usage of ESSENCE to monitor risk factors and incidence of chronic disease and mental health

572 disorders has proliferated since a DoD ESSENCE study utilizing clinic and prescription data to 573 monitor behavioral health in 2004. (55) The Boulder County, Colorado Health Department

574 recently implemented and tested multiple queries to monitor mental health.(56)

575 Addressing ESSENCE utility for chronic diseases in general, the Cook County Illinois health

576 department applied machine learning methods to assess the utility of ESSENCE emergency

577 department (ED) data for monitoring cardiovascular disease (CVD), acute myocardial infarction

578 (AMI), acute coronary syndrome, stable angina, stroke, diabetes, hypertension, asthma, and

579 chronic obstructive pulmonary disease. From correlational validation testing based on eight full

580 years of chief complaint text and electronic medical record data, they concluded that ESSENCE

581 data are suitable for monitoring all of these conditions except stable angina and hypertension "at

582 local, state, or national levels".(57) The Nebraska state health department has used ESSENCE to

583 monitor for CVD for several years, and the Florida state department similarly monitors AMI

584 incidence.(58)

\section{Applications for injury and substance abuse surveillance}

586 An unexpected but arguably the most helpful benefit of ESSENCE to health department users has

587 been to facilitate communication and collaboration among agency divisions. An important 
medRxiv preprint doi: https://doi.org/10.1101/2020.08.14.20175398; this version posted August 17, 2020. The copyright holder for this preprint (which was not certified by peer review) is the author/funder, who has granted medRxiv a license to display the preprint in perpetuity.

It is made available under a CC-BY-NC-ND 4.0 International license .

example in the context of the ongoing opioid overdose crisis has been the strengthening of

589 connections between syndromic surveillance specialists and groups specializing in injury

590 prevention, behavioral health, and drug abuse.

591 Multiple health departments have applied ESSENCE to gain awareness of locations and

592 subpopulations at risk for injuries from falls.(59) The Boston Public Health Commission in

593 Massachusetts used it to monitor for hearing loss, acute depression, and explosion-related injuries

594 in the aftermath of the 2013 Boston Marathon bombing and subsequent manhunt. The St. Louis,

595 Missouri health department established ESSENCE queries for injuries indicative of bomb-making

596 activities.(60)

597 Monitoring for substance abuse has been common among ESSENCE users. The Tri-County

598 Health Department in Colorado uses its system to seek adverse effects of marijuana use.(61) The

599 Florida state department queries for ED visits resulting from synthetic marijuana(62) and for novel

600 street drugs such as Flakka as they become known public health problems.(63) Most recently, the

601 opioid crisis has stimulated intense collaboration including shared syndrome definitions and

602 analytic case-finding tools among geographically scattered institutions using ESSENCE.(64-66) 


\section{CONCLUSIONS}

\section{Lessons Learned}

605 Several principles have driven the success of ESSENCE since its origins in the late 1990's.

606 Versatility: Users have valued the configurability and adaptability of ESSENCE. Default

607 categorization of complex data into syndromic groupings has always been valuable to users who

608 are inexperienced or who do not have the time to formulate or validate their own categories for

609 monitoring. Conversely, health departments with more analysis capacity have long demanded

610 surveillance systems that let them create their own categories to track, and ESSENCE

611 customization with query-building features using both diagnosis codes and free-text has grown

612 along with the sophistication and broadening needs of health department users. Pre-computed,

613 canned analysis products are not found in ESSENCE. However, versatility presents challenges to

614 database design and to the selection and adaptation of statistical analysis tools. Surveillance data

615 evolve with institutional information systems and formats, coding practices, and epidemiological

616 concerns. Users typically cannot wait several minutes for data retrieval and time-consuming model

617 runs. Alerting algorithms applied prospectively to detect disparate events in a wide variety of data

618 types cannot match the detection performance of models developed retrospectively using historical

619 datasets labelled with target events for a particular syndrome. Algorithm baselines in ESSENCE

620 do not reach back for years, not only for storage and computational reasons, but also because for

621 many users' desired data types, stable data or any data are available only within the past year.

622 Hence, ESSENCE alerting algorithms, adapted from published applications of models and control

623 charts in healthcare settings, $(23,67,68)$ use rolling baselines of weeks rather than years. 
medRxiv preprint doi: https://doi.org/10.1101/2020.08.14.20175398; this version posted August 17, 2020. The copyright holder for this preprint (which was not certified by peer review) is the author/funder, who has granted medRxiv a license to display the preprint in perpetuity.

It is made available under a CC-BY-NC-ND 4.0 International license .

625 Facilitating communication: Multiple ESSENCE users have remarked that one of the system's

626 main benefits has been to facilitate communication with other divisions within a health department,

627 with external local and federal agencies, and with care facilities that provide data and can benefit

628 from the broader geographic perspective that a surveillance system enables. Hence, substantial

629 ESSENCE development has occurred in response to user requests for custom analysis

630 comparisons, visualizations, and report formats, allowing overburdened users to concentrate on

631 the task of routine health monitoring. In situations where data-sharing is precluded by county or

632 state regulations, ESSENCE communication tools have enabled information-sharing.

634 Multiple analysis modes: The applicability of individual analysis modes such as univariate and 635 multivariate time series monitoring, spatiotemporal cluster detection, and single case identification

636 all depend on the nature and quality of available data. For example, the spatial scan statistic 637 implemented in ESSENCE can avoid issues of jurisdictional boundaries, but only if data location

638 fields are present and reliably used in the data. In many data sources, the limitation of location

639 fields to zip codes or postal codes restricts the geographic precision of clusters of interest. Health

640 monitors generally need multiple ways to analyze population health data. The clearest example is

641 that ESSENCE users in multiple health departments have discovered unreported cases of

642 reportable disease that traditional sentinel surveillance is expected to communicate to public

643 health. The various analysis modes of ESSENCE provide affordable and sometimes beneficial 644 analytic redundancy. 


\section{Innovation}

646 The development of ESSENCE has produced novel features in areas of complex, disparate data

647 management, analytical methods, and the enhancement of user reporting and collaboration,

648 interrelated efforts to empower health monitors. The data management advances include

649 architecture and data transfer capabilities to meet needs of institutions with varying resources.

650 Analytics advances have required data quality examination methods and alerting algorithms

651 appropriate for diverse data time series that meet rapid response needs and do not require more

652 than a few months of data history. User experience enhancements have included customizable

653 visualization and reporting features that provide unique time- and resource-saving capabilities.

\section{Impact}

655 Recent ESSENCE projects have produced a variety of user capability enhancements. For sharing

656 of information within and across jurisdictions, online features allow users to share what they are

657 doing within ESSENCE with peers and to see what others are querying and find interesting. Text

658 analysis and visualizations facilitate creation of ad hoc local free-text queries. These features

659 provide correlation, trend, and association analytics to help the user determine what terms/phrases

660 queries should or should not include.

661 Back-end tools and checks with visualizations allow the user to monitor closely the local

662 ESSENCE system for data issues and irregularities. These administrative capabilities help

663 managers and users maintain day-to-day system availability and improve visibility of issues that

664 may develop over time.

665 Recently added visualizations and cohort clustering analytic tools for longitudinal assessment 666 allow users to determine categories of patients who use healthcare systems that provide data to 
medRxiv preprint doi: https://doi.org/10.1101/2020.08.14.20175398; this version posted August 17, 2020. The copyright holder for this preprint (which was not certified by peer review) is the author/funder, who has granted medRxiv a license to display the preprint in perpetuity.

It is made available under a CC-BY-NC-ND 4.0 International license .

ESSENCE. These tools can show patient-level usage trends to inform allocation of healthcare resources in a community.

669 The ongoing adaptation of ESSENCE to meet the needs of the understaffed public health practice

670 community has provided a means to share methods and information, though data are often not

671 shareable. The common analytic platform has enabled an evolving user ecosystem of multiple

672 working groups, and the US CDC currently hosts the NSSP Community of Practice, with

673 subgroups including Syndrome Definition, Data Quality, and Technical committees.(69) The

674 Syndrome Definitions committee promotes the analysis of common queries among geographically

675 scattered user sites and US CDC,(70) thus improving communication between local and national

676 health monitors. A primary example is the opioid overdose crisis, a noninfectious threat. In

677 addition to analytics and visualizations to support the activities related to this crisis, developers

678 and users have worked together to acquire additional data sources such as emergency medical

679 incidents, poison center calls, and death records to determine the benefit of fusing information

680 varying in specificity and timeliness into a common surveillance picture to better inform awareness 681 and interventions.

682

683 Future Directions: Challenges to ESSENCE and the Surveillance

684 Community

685 Challenges to public health surveillance span multiple disciplines ranging from epidemiology and 686 applied microbiology to statistics and machine learning and to database and network 687 technology.(71) In ESSENCE, data processing/storage and analytics challenges go hand-in-hand. 688 A major data challenge is to integrate increasingly diverse and granular data sources while 
medRxiv preprint doi: https://doi.org/10.1101/2020.08.14.20175398; this version posted August 17, 2020. The copyright holder for this preprint (which was not certified by peer review) is the author/funder, who has granted medRxiv a license to display the preprint in perpetuity.

It is made available under a CC-BY-NC-ND 4.0 International license .

preserving the essential features of ad hoc user syndrome/case definition and custom real-time analysis and visualization. Public health staff need to extend the power of their systems to all-

691 hazards public health threats and to One Health issues including zoonotic diseases across species,

692 antimicrobial stewardship, and food safety. Users of ESSENCE have long imported non-clinical

693 and non-syndromic data sources such as pharmacy sales and school absentee rates along with

694 traditional medical encounter records.

695 In expansion to address all-hazards threats, data complexity, categorization, and linkage challenges

696 will multiply as genomic, environmental (including remote sensing) and social media data sources

697 are added.

698 Significant advances in disease surveillance will also require meeting key analytics challenges.

699 Beyond the monitoring of individual sources and syndromes with data dashboards, combining

700 disparate data types requires statistical and machine learning tools for appropriate weighting and

701 corroboration of evidence from disparate data types. Analytic fusion efforts employing Bayesian

702 networks and other machine learning tools have been applied in both military and civilian

703 ESSENCE systems (72-75). More efficient and explainable fusion methods will be needed to

704 enable operationalizable forecasting and prediction for greater decision-making power and

705 effective planning and response. Efficient analytic methods will also be needed to determine

706 optimal feature extraction and resultant surveillance value of social media and other nontraditional

707 sources.

708 Lastly, best practices for biosurveillance systems face both human and electronic communication

709 challenges, including interoperability with other electronic systems such as the above-mentioned

710 ASPR DMAT, NPDS, and NEMSIS systems. Despite the preeminence of ESSENCE, as indicated

711 by its adoption as the analytic engine of the CDC Biosense platform and the widespread application 
medRxiv preprint doi: https://doi.org/10.1101/2020.08.14.20175398; this version posted August 17, 2020. The copyright holder for this preprint (which was not certified by peer review) is the author/funder, who has granted medRxiv a license to display the preprint in perpetuity.

It is made available under a CC-BY-NC-ND 4.0 International license .

712 discussed in this paper, the limitations described above and the data gaps exposed by the COVID-

71319 pandemic must be addressed as new threats emerge and data sources proliferate. These

714 challenges must be addressed as ESSENCE matures to expand public health surveillance

715 capabilities and utility beyond what is imaginable today and propel public health toward new

716 frontiers of understanding and action.

717 ACKNOWLEDGEMENTS

718 We would like to acknowledge invaluable assistance from our colleagues and partners. The

719 continued ESSENCE research and development would not have been possible without the support

720 of the CDC, DoD, VA, numerous State and Local health departments, and JHU/APL over the last

72120 years. We especially acknowledge numerous champions and advisors among ESSENCE users

722 who have dedicated time and effort to the betterment of public health surveillance.

723

724 Technical Details of ESSENCE Alerting Algorithms

\section{Univariate temporal alerting algorithms}

726 The default temporal algorithm in ESSENCE is an automated selection between data modeling 727 and control-chart-based algorithms, resorting to a simplistic Poisson distribution-based method if 728 only a few days of recent data are available. The modeling method is adaptive multiple regression,

729 while the control chart-like approach is an adaptive exponentially weighted moving average 730 (EWMA) algorithm. The primary regression and EWMA methods are first discussed separately.

731 Each description below gives a method category, purposes of the method, a brief technical 732 description, key benefits, limitations, and literature sources. 
medRxiv preprint doi: https://doi.org/10.1101/2020.08.14.20175398; this version posted August 17, 2020. The copyright holder for this preprint

\section{Algorithm: Linear Regression}

736 Purposes: This model is an adaptive regression model applied to remove the systematic behavior often seen in time series of daily, syndromic, clinical visit counts and in other surveillance data. The reason for removing these common effects is to avoid bias in identifying unusual

Technical Details: This adaptive, multiple, least-squares regression algorithm contains terms to account for linear trends, day-of-week effects, and holidays. Multipliers for these terms are of an alarm $(17,18)$. Similarly, alarms should be possible on weekends even though visit counts drop off from weekday levels. from the date of the test data by a 2-day buffer intended to keep early outbreak effects from contaminating the training. Extreme data values in the training period are reduced to reasonable values in order to avoid exaggerated predictions. This outlier correction for model inference avoids loss of sensitivity in the weeks after either data problems or true outbreaks. The regression multipliers are recomputed each day for calculation of a predicted count based on

758 Benefits: The main benefit is avoiding alerting bias resulting from expected data trends. The length count, scales the excess by the standard error of regression, and applies a statistical hypothesis test to determine whether to signal an alert. The test is a Student's t distribution at significance levels of $1 \%$ for red alerts and $5 \%$ for yellow alerts, with the number of degrees of freedom determined by the number of regression covariates and the baseline length(19). Covariates and training intervals were chosen to obtain maximum sensivity for detection of injected signals at manageable background alert rates. for the training baseline is critical. Based on performance comparisons among multiple baseline lengths, it was chosen to be short and recent enough to capture seasonal time series behavior but long enough to smooth out daily fluctuations. Separate multipliers are updated so that a data source with regular but unusual patterns such as high weekend counts will be modeled correctly. While a better fit may often be obtained with a more complex model for a given data stream with a certain syndromic filter for a certain subregion and analysis of 
medRxiv preprint doi: https://doi.org/10.1101/2020.08.14.20175398; this version posted August 17, 2020. The copyright holder for this preprint

sufficient data history, the current regression approach is relatively robust across time series employed in ESSENCE.

Limitations: If this algorithm is applied to a data series without the baseline weekly and seasonal behavior, the model will not explain the data well, and the detection sensitivity and specificity will be decreased. The automated switch in the default method is applied for this reason. There is no claim of optimal modeling for a given time series. This general-use implementation does not assume the availability of a denominator variable such as the total visit count that can be used to adjust the counts to emulate series of rates rather than counts. This adjustment has been implemented in particular versions of ESSENCE and in past versions of Biosense $(20,21)$ and could be added as an option.

\section{Algorithm:Adaptive Exponentially Weighted Moving Average (EWMA)}

Technical Details: This algorithm compares a weighted average of the most recent visit counts to modeled in the regression algorithm. It is more applicable for Emergency Department data from certain hospital groups and for time series with small counts (daily average below 10) because of the limited case definition or chosen geographic region.(22)

$$
\text { the most influence to the most recent observations. Two weightings are applied: the first gives }
$$
negligible weight to observations over 3 days old and is designed to detect sudden events where most outbreak cases affect data within a few days. The second weighting distributes influence further over the past week for sensitivity to more gradual outbreaks. These weightings emulate a dual strategy published for the hospital setting.(23) The monitored weighted averages are the Sk given by:

$$
\mathrm{S}_{\mathrm{k}}=\omega \mathrm{S}_{\mathrm{k}-1}+(1-\omega) \mathrm{X}_{\mathrm{k}}
$$

for a constant smoothing coefficient $\omega$ with $0<\omega<1$ and $X_{k}$ as the successive data counts, with $\mathrm{X}_{0}=0$ and $\mathrm{S}_{0}=$ half the alerting threshold for prompt sensitivity. (Occasionally a useful starting value for $\mathrm{X}_{0}$ is known, but restarts may occur for many reasons, so the conservative initialization to 0 is used.) For separate monitoring of sudden and gradual events, smoothing coefficients $\omega=0.9$ and 0.4 are used. For both weighted averages, the 4 -week baseline mean 
medRxiv preprint doi: https://doi.org/10.1101/2020.08.14.20175398; this version posted August 17, 2020. The copyright holder for this preprint

is subtracted, with a 2-day buffer period to separate the baseline from the counts being tested.

The rationale for the baseline length was the same as described above for the regression method above. The test statistic is then $\left(\mathrm{S}_{\mathrm{k}}-\mu \mathrm{k}\right) / \sigma_{\mathrm{k}}$, where $\mu_{\mathrm{k}}$ and $\sigma_{\mathrm{k}}$ are baseline mean and standard deviation. As in the regression method, the hypothesis applied to determine alerting is a Student's t distribution at significance levels of $1 \%$ for red alerts and $5 \%$ for yellow alerts. The avoid excessive alerts.(19)

Benefits: This method gives sensitivity to both sudden and gradual outbreaks and has demonstrated prompt alerting capability. It is less susceptible than the Early Aberration Reporting System (EARS) methods C1, C2, and C3 to trends and to day-of-week effects. The added recovery features handle the most common problems in the data acquisition chain. Alerting is indirectly adjusted for the data distribution via the standardized residual test statistic, which provides a safeguard against excessive alerting when counts are small.

Limitations: This algorithm applied to pure daily counts does not control for expected trends or cyclic effects as in the regression method.

\section{Algorithm: Poisson/Regression/EWMA (default)}

815 Categorization: Automated switch between data model and control chart

816 Purposes: Many researchers and developers have applied complex statistical models to 817 surveillance data for prediction and detection. However, the predictive capability of a model 818 varies according to the specific data stream and how it is filtered and aggregated. This 819 capability may also be affected by data behavior changes that result from seasonal variations, 820 population shifts, and changes in the informatics. To account for such day-to-day changes, 821 ESSENCE automatically monitors its predictive capability of its regression model each day. 822 When this test fails, indicating that the model is not helpful for explaining the data, the system 823 switches to the EWMA adaptation described above. The result is that the regression model is 824 usually applied for the common respiratory and gastrointestinal syndrome classifications 
medRxiv preprint doi: https://doi.org/10.1101/2020.08.14.20175398; this version posted August 17, 2020. The copyright holder for this preprint (which was not certified by peer review) is the author/funder, who has granted medRxiv a license to display the preprint in perpetuity.

It is made available under a CC-BY-NC-ND 4.0 International license .

$$
\text { applied to county-level data, but EWMA is more commonly applied to rare syndrome data. }
$$
For situations where less than a week of recent baseline data exists, a simple Poisson detector is applied. Such situations include new start-ups and more common restarts after long (severalweek) intervals of missing data.

Technical Details: Details for the separate regression and EWMA methods are given in the preceding pages. The adjusted $\mathrm{R}^{2}$ coefficient for the regression is tested each day. This coefficient does not give the quality of regression but is employed here specifically as a measure of daily predictive capability using an empirically derived threshold criterion. When the data pass this test, the model is assumed to have explanatory value, and the regression algorithm is applied. When the data fail this test, the EWMA algorithm is used. The Poisson distribution test is applied when less than a week (3-6 days) of recent data is available. A Poisson distribution is assumed with mean and variance equal to the mean of the recent counts. An alert is issued if the current count exceeds this mean and if probability that the current count was drawn from this distribution is less than 1\% (red alert) or 5\% (yellow alert). Practical safeguards for the composite method are as described in the regression and EWMA sections above.(19)

Benefits: This algorithm is the default because it is designed to avoid mismatching the method to the data. The regression model accounts for the expected data trends when they are seen in the baseline. When they are absent because of the case definition used to filter the data, because of the size of the monitored region, or because of data problems, alerting is based on the EWMA algorithm.

Limitations: The goodness-of-fit test occasionally misclassifies the data. The test is set to err toward the more conservative EWMA to avoid misfitting the data model.

\section{Algorithm: C1, C2, and C3}

\section{Categorization: Adaptive Control Chart}

Purposes: To purpose is to detect general data aberrations. Algorithms C1, C2, and C3 of the Early Aberration Reporting System (EARS) developed at the Centers for Disease Control and Prevention are used in many U.S. states and in numerous foreign countries.(24) They are 
medRxiv preprint doi: https://doi.org/10.1101/2020.08.14.20175398; this version posted August 17, 2020. The copyright holder for this preprint

included in the ESSENCE suite because of their wide application. While they lack many of the features described above, their simplicity has both benefits and limitations.

Technical Details: The $\mathrm{C} 1$ algorithm subtracts the daily count from the mean of a moving baseline ending the previous day. In effect, it then divides this difference by the standard deviation of counts in that baseline. If the result exceeds 3 , indicating an increase above the mean of more

Benefits: The methods are easy to understand and widely known.(25-27) than 3 standard deviations, an alert is issued. The $\mathrm{C} 2$ algorithm does the same calculation but

Limitations: Like the EWMA, the methods take no account of systematic data behavior such as day-of-week effects or seasonal trends. C3 is the only one of these methods with sensitivity to gradual outbreak effects, but it is known to produce high alarm rates. For all three methods, threshold data values for alerting may fluctuate noticeably from day to day.

875 Categorization: False Discovery Rate processing of multiple alerts

876 Purpose: The parallel monitoring problem is the monitoring of multiple separate time series 877 representing different physical locations, such as counties or treatment facilities, possibly stratified by other covariates such as syndrome type or age group. The purpose of the Summary Alert Algorithm is to maintain sensitivity while limiting the number of alerts that arise from testing the numerous resulting time series.

Multiple testing can lead to uncontrolled alert rates as the number of data streams increases. For example, suppose that a hypothesis test is conducted on a time series of daily diagnoses of influenza-like illness. In a one-sided test, this test results in a statistic whose value in some 

Type I error probability of $\alpha$, the probability is then $(1-\alpha)$ that an alert will not occur in the distribution assumed for background data. Thus, for the parallel monitoring problem of interest here, if such tests are applied to $\mathrm{N}$ independent data streams, the probability that no background alerts occur is $(1-\alpha)^{N}$, which decreases quickly for practical error rates $\alpha$. For a single-test error rate of $\boldsymbol{\alpha}=0.05$, for example, the probability of at least one background alert exceeds 0.5 if more than 13 independent tests are applied.

Technical Details: For $\mathrm{N}$ tests, where $\mathrm{N}$ is the number of combinations of region, syndrome, age group, and any other covariates affecting the number of tests, let $P_{(1)}, \ldots, P_{(N)}$ be the $p$-values sorted in ascending order, an ordering that puts the smallest and most significant p-value first. The Summary Alert method applies the Simes-Seeger-Eklund criterion to reject the combined null hypothesis of no anomaly for any series.(28) The null hypothesis is rejected if for some $j^{*}, j^{*}=1, . . \mathrm{N}, P_{\left(j^{*}\right)}<j^{*} \alpha / N$. To interpret this condition, note that for the most significant p-value, an alert requires that $P_{(I)}<\alpha / N$, the strict Bonferroni bound. If $\alpha=0.01$ and $\mathrm{N}=50$, then the condition becomes $P_{(l)}<0.0002$. For the least significant $\mathrm{p}$-value, the condition is simply $P_{(N)}<\alpha$, highly unlikely for the weakest result.

If this condition is satisfied for any $\mathrm{j}^{*}$, then test results are considered alerts for all $\mathrm{j}<\mathrm{j}^{*}$.(29)

911 Limitations: If one of the p-values crosses the adjusted threshold, it is not obvious for

912 epidemiological or other reasons which tests to consider anomalous. Most users have followed

913 the natural procedure described by Simes to consider all p-values less than $P_{\left(j^{*}\right)}$ as individual

914 alerts. Another limitation is that in general the time series are not statistically independent. 
medRxiv preprint doi: https://doi.org/10.1101/2020.08.14.20175398; this version posted August 17, 2020. The copyright holder for this preprint

For situations where dependence is known, Hommel recommended the condition $P_{(j)}<j$. be requested and dependence can change, the above condition with $\mathrm{C}=1$ is applied.

\section{Spatial cluster determination}

920 Categorization: Spatial Scan Statistics

921 Purpose: A problem with sophisticated temporal detectors is choosing the appropriate size and 922 location of the collection region for time series counts. If this region is too small or mislocated, 923 cases may be missed and the baseline data may not have enough structure, but if the region is too large, the scale and variability of the large-scale time series may reduce sensitivity by masking clusters of interest. We apply spatiotemporal scan statistics in an attempt to promptly localize public health problems. For ESSENCE, JHU/APL built and implemented a Java version of the algorithm implemented in the SaTScan software of Martin Kulldorff originally developed for spatial surveillance of cancer and subsequently used and enhanced for many types of hotspot detection.(31)

Technical Details: The null hypothesis is that the set of data subregions (often zip codes) in the recent time interval tested forms a random sample from an expected spatial distribution of cases. The expected distribution is not uniform over subregions but reflects a "customary" spatial case spread that reflects urban/suburban case ratios or other factors. ESSENCE implementation calculates the expected spatial distribution using recent case counts from a sliding baseline interval. In effect, the code is similar to a common application of SaTScan, the space-time permutation scan statistic, restricted to test cases from only the most recent time interval and assuming circular clusters.(32)

As in SaTScan, the method calculates a test statistic for each candidate cluster. The test statistic in the ESSENCE implementation is Kulldorff's Poisson log likelihood ratio. The set of candidate clusters is generated by scanning over a set of cluster center locations, often taken as centroids of all zip codes in the dataset, and considering all circles within a maximum radius of each center, where the number of circles is limited by the number of data subregions within each radius. The maximum test statistic over these candidates is then tested for significance. 
medRxiv preprint doi: https://doi.org/10.1101/2020.08.14.20175398; this version posted August 17, 2020. The copyright holder for this preprint

Statistical significance inference does not depend on a theoretical distribution but on repeated trials on simulated datasets randomly drawn using the baseline distribution. For each such trial, the algorithm uses the same scanning procedure to derive a trial maximum.

For assessing the significance of the maximum test statistic over all observed clusters, the ESSENCE code uses the Gumbel distribution method.(33) The code collects 99 trial maxima, fits a Gumbel distribution to these values, and uses the fitted distribution to assign a p-value to the test statistics of clusters found in the original data. The observed cluster with the maximum test statistic is considered significant if its p-value is below a predetermined threshold, often set to 0.01 . This threshold criterion can yield multiple significant clusters in a given run if more than one candidate cluster yields a test statistic whose p-value is below the threshold. For each significant case cluster, the system shows the location, extent, and degree of significance using the GIS software.

Benefits: The ESSENCE Java implementation inherits features that have popularized SaTScan. Potential clusters of interest are localized without bias regarding the center or extent of the cluster as well as the spatial resolution of the data allows. As noted in Kulldorff, Heffernan, et al., the empirical significance testing with many repeated trials takes "into account the multiple testing stemming from the many potential cluster locations and sizes evaluated.’(32)

Limitations: The most important limitation, applicable also to SaTScan and to all other spatial or space-time cluster detection methods, is that the usefulness of the method strongly depends on the reliability of the expected spatial distribution. The use of census-based distributions, insurance eligibility lists, regression models, and other means have been used to derive the expected distribution. The method implemented in ESSENCE infers this distribution from recent data separated from the test date(s) by a 2-day buffer. Evaluation of statistically significant clusters for epidemiological significance is a nontrivial task which may be exacerbated if the number of significant clusters is misleading or excessive because the expected distribution is unrepresentative or because investigation resources are insufficient.

The use of this popular approach for prospective use has been criticized despite numerous applications and published real-life successes,(34) and the ESSENCE implementation lacks the prospective adjustment in SaTScan attempting to manage cluster rates for multiple successive runs. The ESSENCE implementation also does not support elliptical cluster shapes, 
medRxiv preprint doi: https://doi.org/10.1101/2020.08.14.20175398; this version posted August 17, 2020. The copyright holder for this preprint (which was not certified by peer review) is the author/funder, who has granted medRxiv a license to display the preprint in perpetuity.

It is made available under a CC-BY-NC-ND 4.0 International license .

simultaneous clustering of multiple data sources, or test statistics other than the Poisson log likelihood ratio. The user with a sufficiently detailed dataset and an application that requires these extended SaTScan features should be aware of these limitations.

\section{Time-of-arrival aberration detection}

Categorization: Multiple Automated Hypothesis tests

Purpose: This algorithmic approach was implemented to find and display unusual clusters of syndromically related emergency department visits by patients arriving for care within a short time interval.

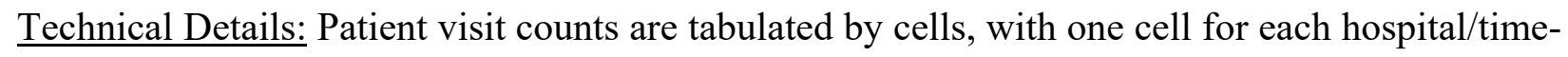
interval/sub-syndrome combination. See Figure 1.

Figure 1: Schematic of time-of-arrival filtering and anomaly detection process

- For the visit counts in each cell, a Poisson or negative binomial test is chosen using the last 60 days of visit counts for that cell. The Poisson distribution is used unless the count variance exceeds the mean by a factor of 1.1 or greater, and then the time series is considered overdispersed. This situation occurs for relatively few cells, generally corresponding to the more common (sub)syndromes for the largest hospitals at the busiest times when most alerts would be generated. For this situation, a negative binomial distribution is assumed. Parameter settings and distribution types were derived from testing on several years of patient visit records from a variety of large and small hospitals.

- Once the distribution is chosen, parameters for each cell are calculated from the 60-day baseline. For each cell, an alert is then flagged if the current count exceeds the upper limit threshold for the chosen distribution based on a preselected $\mathrm{p}$-value.

- Based on empirical results using 12 years of data from 134 hospital EDs from a large state with labeled events, a threshold $\mathrm{p}$-value of $\mathrm{p}^{*}=10-4$ (0.0001) was chosen.

- Time intervals for the cells are $30 \mathrm{~min}$., $60 \mathrm{~min}$. beginning on the hour, and $60 \mathrm{~min}$. beginning on the half hour, again a result of empirical testing. 
medRxiv preprint doi: https://doi.org/10.1101/2020.08.14.20175398; this version posted August 17, 2020. The copyright holder for this preprint (which was not certified by peer review) is the author/funder, who has granted medRxiv a license to display the preprint in perpetuity.

It is made available under a CC-BY-NC-ND 4.0 International license.

1004

1005

1006

1007

1008

1009

1010

1011

1012

1013

1014

1015

1016

1017

1018

1019

1020

1021

1022

1023

1024

1025

1026

1027

1028

1029

1030

1031

1032

1033

- Practical overrides are implemented based on observed cell counts. At least three observed cases are required for an alert. This minimum may be increased for more common syndromes. Mandatory alerts may also be implemented for certain subsyndrome/count combinations, such as subsyndromes for severe illness, regardless of the hypothesis test.

Benefits: In validation testing to monitor visit clusters for 51 subsyndromes for 134 hospitals at the time intervals above with the chosen p-value threshold, alert rates were consistently manageable and found all known clusters from a small historical collection of events except for two groups of 3-4 visits at very busy times. The alert burden was still manageable at the county level when anomalous clusters for all hospitals within each county were combined. The simplicity of this approach allows multiple daily runs and adaptation to new improvised subsyndromes with rapid system response without impact on routine processing.

Limitations: The hypothesis tests include no direct modeling of seasonality or other systematic data behavior. They were implemented to enable county-level processing, and validation was conducted on a 12-year historical dataset from one state. Expanding the computational load to include much larger sets of hospitals or syndrome groups with limited investigation capability may require recalibration ( $\mathrm{p}$-value threshold, minimum alert counts) or an alternate approach to retain sensitivity with manageable alerting.

\section{Identification of term-based free-text anomalies}

Categorization: Hypothesis test for excessive occurrence of selected chief complaint terms Purpose: This algorithm was implemented to point out unusual distributions of chief complaint terms of interest without dependence on syndrome definitions.

Technical Details: For each term in any chief complaint in the most recent time interval, the number of chief complaints containing that term in this interval is tested relative to the number of chief complaints containing same term in a much larger sliding baseline interval, assumed to be representative of customary data.

- The algorithm forms $2 \times 2$ contingency tables whose entries are: 
$\mathrm{A}=$ number of recent chief complaints with the term,

- For many such tables with small cell counts, Fisher's Exact Test is applied to alert when the probability that count of the term of interest is $\geq$ A, given the contingency table's marginal totals, is below a critical p-value.

- If the smaller of B and C is larger than 1000, then a chi-square test is applied to the same contingency table with negligible loss of accuracy. The critical threshold is then applied to half the resultant (two-sided) p-value to determine anomalous terms.

- Results are shown only for candidate terms that have not been previously eliminated because they are stopwords with no informational content (such as "the", "if", "all") or because users have previously added them to a list of terms to be ignored (such as "patient", “complaint", “test").

1054 Benefits: With the above p-value threshold and settings, this method detects as few as three 1055 instances of unusual terms (place names, rare signs/symptoms) and unusual concentrations of interesting common terms while averaging from 0-4 anomalous terms per day over small and large hospitals. Inspecting chief complaints containing each of a small number of terms each day and disqualifying some terms from further consideration is a manageable task that can uncover clusters of visits that could be missed by syndromic methods. In testing with historic data, chief complaints containing anomalous terms found with the strict p-value threshold adopted have included small clusters of visits resulting from documented events of food poisoning and heat-related illness. This analysis has also found new abbreviations used by hospitals in their chief complaints. These new abbreviations can then be added to the Chief Complaint Processor to improve syndrome and subsyndrome categorization. 
Limitations: While the simplicity of this method avoids impact on daily ESSENCE processing or user investigation of large collections of distributed data streams, the method has no means to interpret anomalous terms, identify phrases with multiple terms, or distinguish topics of concern in chief complaints that may not share specific terms. The only preprocessing of freetext terms is the application of ESSENCE Chief Complaint Processor spell checking and future anomalies. The method is subject to effects of changing terminology (street drug names, triage vocabulary and abbreviations), and the user should be aware of current perceived health 1075 threats and corresponding emergency/urgent care language. outbreak detection system using syndromic data in the greater Washington DC area. Am J Prev Med. 2002;23(3):180-6. Based Epidemics (ESSENCE II). J Urban Health. 2003;80(2 Suppl 1):i32-42. Morb Mortal Wkly Rep. 2004;53 Suppl:152-8. ESSENCE (October 2016) 2016 [updated 10/14/2016.

1087 https:/www.cdc.gov/nssp/biosense/docs/biosense-platform-quick-start-guide-for$1088 \quad$ essence.pdf]. 
medRxiv preprint doi: https://doi.org/10.1101/2020.08.14.20175398; this version posted August 17, 2020. The copyright holder for this preprint (which was not certified by peer review) is the author/funder, who has granted medRxiv a license to display the preprint in perpetuity.

It is made available under a CC-BY-NC-ND 4.0 International license .

5. Kumar RS, White JR. Impact of the NSSP's transition to ESSENCE on chief complaint fieldbased syndromes. Online J Public Health Inform. 2018;10(1).

6. IBM Knowledge Center. Overview of Rational Rhapsody Poughkeepsie, NY USA: IBM Knowledge Center; 2020 [Available from: https://www.ibm.com/support/knowledgecenter/SSB2MU_8.3.0/com.ibm.rhp.overview.doc/t opics/rhp_c_po_rr_product_overview.html.]

7. HealthCare Integrations. Interface Monitor 2019 [updated September 1, 2019. Available from: https://interfacemonitor.com/?gclid=EAIaIQobChMIn8D18s_T5gIVBmyGCh0EbQdGEAAY ASAAEgKmUfD_BwE.]

8. Apache Software Foundation. The Apache Groovy programming language Wakefield, MA: Apache Software Foundation; 2019 [Available from: https:/groovy-lang.org/.

9. Apache Software Foundation. Apache Tomcat 2019 [

10. Foundation OSG. GeoServer. 2.16.2 ed. Beaverton, Oregon USA: Open Source Geospatial Foundation; 2020.

11. Office of the Assistant Secretary for Preparedness and Response. Disaster Medical Assistance Teams Washington D.C., USA: U.S. Department of Health and Human Services; 2019 [updated September 9, 2017. Available from: https://www.phe.gov/Preparedness/responders/ndms/ndms-teams/Pages/dmat.aspx.

12. American Association of Poison Control Centers. AAPCC National Poison Data System Arlington, Virginia USA: American Association of Poison Control Centers; 2019 [December 18, 2019]. Available from: https://www.npds.us.

13. Sniegoski CA. Automated syndromic classification of chief complaint records. Johns Hopkins Apl Technical Digest. 2004;25(1):68-75. 
medRxiv preprint doi: https://doi.org/10.1101/2020.08.14.20175398; this version posted August 17, 2020. The copyright holder for this preprint (which was not certified by peer review) is the author/funder, who has granted medRxiv a license to display the preprint in perpetuity.

It is made available under a CC-BY-NC-ND 4.0 International license .

1112 14. Munroe JG, Straver R, Rubino H, Pritchard S, Atrubin D, Hamilton JJ. MERS PUI

1113 Surveillance and Restrospective Identification in ESSENCE-FL, 2013-2015. Online J Public

1114 Health Inform. 2017;9(1).

1115 15. Atrubin D. Syndromic Surveillance Identifies Unreported Cases of Zika Virus Disease,

1116 2016-20172019 [updated January 15, 2019. Available from:

1117 https://www.cdc.gov/nssp/documents/success-stories/NSSP-Success-Story-florida-zika-

1118 508.pdf.]

1119 16. Wiese M, Atrubin D, McDougle W, Lewis J. Effectiveness of Using a Chief Complaint and

1120 Discharge Diagnosis Query in ESSENCE-FL to Identify Possible Tuberculosis Patients and

1121 Contacts in Hillsborough County, Florida. Online J Public Health Inform. 62014.

1122 17. Xing J, Burkom H, Tokars J. Method selection and adaptation for distributed monitoring of

1123 infectious diseases for syndromic surveillance. J Biomed Inform. 2011;44(6):1093-101. doi:

1124 10.16/j.jbi.2011.08.012. Epub Aug 24.

1125 18. Brillman JC, Burr T, Forslund D, Joyce E, Picard R, Umland E. Modeling emergency

1126 department visit patterns for infectious disease complaints: results and application to disease

1127 surveillance. BMC Med Inform Decis Mak. 5. England2005. p. 4.

1128 19. Burkom HS, Elbert Y, Magruder SF, Najmi AH, Peter W, Thompson MW. Developments in

1129 the Roles, Features, and Evaluation of Alerting Algorithms for Disease Outbreak Monitoring.

1130 Johns Hopkins APL Technical Digest. 2008;27(4):313.

1131 20. Zhou H, Burkom H, Winston C, Dey A, Ajani U. Practical comparison of aberration

1132 detection algorithms for biosurveillance systems. J Biomed Inform. 2015. 
medRxiv preprint doi: https://doi.org/10.1101/2020.08.14.20175398; this version posted August 17, 2020. The copyright holder for this preprint (which was not certified by peer review) is the author/funder, who has granted medRxiv a license to display the preprint in perpetuity.

It is made available under a CC-BY-NC-ND 4.0 International license .

1133 21. Tokars JI, Burkom H, Xing J, English R, Bloom S, Cox K, et al. Enhancing time-series

1134 detection algorithms for automated biosurveillance. Emerg Infect Dis. 2009;15(4):533-9. doi:

$1135 \quad$ 10.3201/eid1504.080616.

1136 22. Ryan TP. Statistical methods for quality improvement: John Wiley \& Sons; 2011.

1137 23. Morton AP, Whitby M, McLaws ML, Dobson A, McElwain S, Looke D, et al. The

1138 application of statistical process control charts to the detection and monitoring of hospital-

1139 acquired infections. J Qual Clin Pract. 2001;21(4):112-7.

1140 24. Hutwagner L, Thompson W, Seeman GM, Treadwell T. The bioterrorism preparedness and

1141 response Early Aberration Reporting System (EARS). J Urban Health. 2003;80(2 Suppl

1142 1):i89-96.

1143 25. Zhu Y, Wang W, Atrubin D, Wu Y. Initial evaluation of the early aberration reporting

1144 system--Florida. MMWR Morb Mortal Wkly Rep. 54 Suppl. United States2005. p. 123-30.

1145 26. Lawson BM, Fitzhugh E, S. H, Hutwagner L. From Implementation to Automation --- A

1146 Step-by-Step Approach to Developing Syndromic Surveillance Systems from a Public Health

1147 Perspective 2020 [Available from:

1148 https://www.cdc.gov/mmwr/preview/mmwrhtml/su5301a60.htm.

1149 27. Zhang H, Li Z, Lai S, Clements ACA, Wang L, Yin W, et al. Evaluation of the Performance 1150 of a Dengue Outbreak Detection Tool for China. PLoS One. 92014.

1151 28. Simes RJ. An Improved Bonferroni Procedure for Multiple Tests of Significance.

$1152 \quad$ Biometrika. 1986;73(3):751-4.

1153 29. Hommel G. A stagewise rejective multiple test procedure based on a modified. 2019. 
medRxiv preprint doi: https://doi.org/10.1101/2020.08.14.20175398; this version posted August 17, 2020. The copyright holder for this preprint (which was not certified by peer review) is the author/funder, who has granted medRxiv a license to display the preprint in perpetuity.

It is made available under a CC-BY-NC-ND 4.0 International license .

1154 30. Benjamini Y, Hochberg Y. Controlling the False Discovery Rate: A Practical and Powerful

1155 Approach to Multiple Testing. Journal of the Royal Statistical Society Series B

1156 (Methodological). 1995;57(1):289-300.

1157 31. Kulldorff M. A spatial scan statistic. Communications in Statistics-Theory and Methods.

$1158 \quad 1997 ; 26(6): 1481-96$.

1159 32. Kulldorff M, Heffernan R, Hartman J, Assuncao R, Mostashari F. A space-time permutation

1160 scan statistic for disease outbreak detection. Plos Medicine. 2005;2(3):216-24.

1161 33. Abrams AM, Kleinman K, Kulldorff M. Gumbel based p-value approximations for spatial 1162 scan statistics. International Journal of Health Geographics. 2010;9.

1163 34. Correa TR, Assuncao RM, Costa MA. A critical look at prospective surveillance using a $1164 \quad$ scan statistic. Stat Med. 2015;34(7):1081-93.

1165 35. Franz DR, Jahrling PB, Friedlander AM, McClain DJ, Hoover DL, Bryne WR, et al. Clinical 1166 recognition and management of patients exposed to biological warfare agents. Jama. $1167 \quad$ 1997;278(5):399-411.

1168 36. Marsden-Haug N, Foster VB, Gould PL, Elbert E, Wang H, Pavlin JA. Code-based 1169 syndromic surveillance for influenzalike illness by International Classification of Diseases, $1170 \quad$ Ninth Revision. Emerg Infect Dis. 2007;13(2):207-16.

1171 37. Hopkins RS, Kite-Powell A, Goodin K, Hamilton JJ. The Ratio of Emergency Department 1172 Visits for ILI to Seroprevalence of 2009 Pandemic Influenza A (H1N1) Virus Infection, 1173 Florida, 2009. PLoS Curr. 2014;6.

1174 38. Schirmer P, Lucero C, Oda G, Lopez J, Holodniy M. Effective detection of the 2009 H1N1 1175 influenza pandemic in U.S. Veterans Affairs medical centers using a national electronic 1176 biosurveillance system. PLoS One. 2010;5(3):e9533. 
medRxiv preprint doi: https://doi.org/10.1101/2020.08.14.20175398; this version posted August 17, 2020. The copyright holder for this preprint (which was not certified by peer review) is the author/funder, who has granted medRxiv a license to display the preprint in perpetuity.

It is made available under a CC-BY-NC-ND 4.0 International license .

1177 39. Burkom HS BA, Paladini M, Revere D, McIntyre A. Analytic Evaluation of a

1178 Standardization Effort for the Distribute Emergency Department Surveillance Project.

1179 Proceedings of the Joint Statistical Meetings. 2011:1450-62.

1180 40. Kuspis K, Jagger M, Powell M, Hillwig R. Recognizing Recreational Water Exposure and

1181 Habituating HAB Surveillance in ESSENCE. 10. 2018.

1182 41. Bemis K, Frias M, Patel MT, Christiansen D. Using an Emergency Department Syndromic

1183 Surveillance System to Evaluate Reporting of Potential Rabies Exposures, Illinois, 2013-

1184 2015. Public Health Rep. 2017;132(1 Suppl):59S-64S.

1185 42. Collins J. Arizona Monitors Transfer of Patients with RMSF from Tribal Lands to Facilities

1186 in Maricopa County 2019 [

1187 43. O'Connell EK, Zhang G, Leguen F, Llau A, Rico E. Innovative uses for syndromic

1188 surveillance. Emerg Infect Dis. 2010;16(4):669-71.

1189 44. NCoP. NSSP Knowledge Repository: Syndrome Definition Subcommittee Calls 2020

1190 [Available from: https://www.cste.org/page/nsspcop.

1191 45. Powell M, Boyd L. Tracking Health Effects of Wildfires: The Oregon ESSENCE Wildfire

$1192 \quad$ Pilot Project. 9. 2017.

1193 46. Wiedeman C, Shaffner J, Squires K, Leegon J, Murphree R, Petersen PE. Monitoring Out-

1194 of-State Patients during a 2017 Hurricane Response using ESSENCE. 10. 2018.

1195 47. Baer A, Elbert Y, Burkom HS, Holtry R, Lombardo JS, Duchin JS. Usefulness of syndromic 1196 data sources for investigating morbidity resulting from a severe weather event. Disaster Med

1197 Public Health Prep. 2011;5(1):37-45. doi: 10.1001/dmp.2010.32. Epub Sep 28. 
medRxiv preprint doi: https://doi.org/10.1101/2020.08.14.20175398; this version posted August 17, 2020. The copyright holder for this preprint (which was not certified by peer review) is the author/funder, who has granted medRxiv a license to display the preprint in perpetuity.

It is made available under a CC-BY-NC-ND 4.0 International license .

48. Falise AM, Griffin I, Fernandez D, Rodriguez X, Moore E, Barrera A, et al. Carbon Monoxide Poisoning in Miami-Dade County Following Hurricane Irma in 2017. Disaster Med Public Health Prep. 2019;13(1):94-6.

49. Kyle Ryff M, Melissa Powell M, Michelle Barber M, and Laurel Boyd M, all of whom spent significant time in the development of OPHD's Rhapsody engine and informatics infrastructure. This publication was supported by Cooperat, Laing R. Integrating Poison

50. Eggers C, Passman D, Chern A, Spector D, Kite-Powell A, Davis T, et al. Operational Experience: Integration of ASPR Data into ESSENCE-FL during the RNC. 5. 2013.

51. Lombardo JS, Sniegoski CA, Loschen WA, Westercamp M, Wade M, Dearth S, et al. Public Health Surveillance for Mass Gatherings. Johns Hopkins Apl Technical Digest. 2008;27(4):347-55.

52. Jagger MA, Jaramillo S, Boyd L, Johnson B, Reed KR, Powell M. Mass Gathering

1214 Surveillance during the 58th Presidential Inauguration-District of Columbia, January 2017.

1215 Disaster Med Public Health Prep. 2019:1-7.

1216 54. Hoy D, Mercier A, White P, Saketa ST, Roth A, Souares Y, et al. Using SAGES

1217 OpenESSENCE for Mass Gathering Events. Online J Public Health Inform. 2015;7(1).

1218 55. Pavlin JA, Murdock P, Elbert E, Milliken C, Hakre S, Mansfield J, et al. Conducting

1219 population behavioral health surveillance by using automated diagnostic and pharmacy data $1220 \quad$ systems. MMWR Suppl. 2004;53:166-72. 
medRxiv preprint doi: https://doi.org/10.1101/2020.08.14.20175398; this version posted August 17, 2020. The copyright holder for this preprint (which was not certified by peer review) is the author/funder, who has granted medRxiv a license to display the preprint in perpetuity.

It is made available under a CC-BY-NC-ND 4.0 International license .

1221

1222

1223

1224

1225

1226

1227

1228

1229

1230

1231

1232

1233

1234

1235

1236

1237

1238

1239

1240

1241

1242

1243

56. Sussman L, Brown T. Using ESSENCE to Meet Local Needs for Mental Health Data: Query \& Results. Online J Public Health Inform. 2019;11(1).

57. Demian Christiansen KB, and Victoria Persky, Patel MT. Assessment of the use of ED Chief Complaint Data for monitoring Chronic Diseases. 10. 2018.

58. Culpepper AB, Atrubin D, Hamilton JJ, Cui D. Day of Week Analysis of Myocardial Infarctions Using ESSENCE-FL Emergency Department Data. 8. 2016.

59. Hensley J, Gonzalez S, Stover D, Safranek T, Qu M. Evaluation of ESSENCE Syndromic Definitions for ED Visits Related to Falls in Icy Weather. Online J Public Health Inform. 112019.

60. Torgerson A. Using ESSENCE to Detect Bomb-Making Activity: What's Appropriate? 10. 2018.

61. Marx GE, Chen Y, Askenazi M, Albanese BA. Syndromic Surveillance of Emergency Department Visits for Acute Adverse Effects of Marijuana, Tri-County Health Department, Colorado, 2016-2017. Public Health Rep. 2019;134(2):132-40.

62. Wiese M, Clark CR. Analysis of ED and UCC Visits Related to Synthetic Marijuana in ESSENCE-FL, 2010-2015. Online J Public Health Inform. 82016.

63. Atrubin D, Bowden S, Hamilton JJ. Using Syndromic Surveillance to Rapidly Describe the Early Epidemiology of Flakka Use in Florida, June 2014 - August 2015. 8. 2016.

64. Hudson T-ML, Klekamp BG, Matthews SD. Local Public Health Surveillance of HeroinRelated Morbidity and Mortality, Orange County, Florida, 2010-2014:. Public Health Reports. 2017.

65. Jacquemin BJ, Hamby T, Tsai S. Using probabilistic matching to improve opioid drug overdose surveillance, New Jersey. Online J Public Health Inform. 2019;11(1). 
medRxiv preprint doi: https://doi.org/10.1101/2020.08.14.20175398; this version posted August 17, 2020. The copyright holder for this preprint (which was not certified by peer review) is the author/funder, who has granted medRxiv a license to display the preprint in perpetuity.

It is made available under a CC-BY-NC-ND 4.0 International license .

1244 66. Hou W, Brutsch E, Dunn AC, Burnett CL, Dimond MP, Nakashima AK. Using Syndromic

1245 Data for Opioid Overdose Surveillance in Utah. Online J Public Health Inform. 2018;10(1).

1246 67. Unkel S, Farrington CP, Garthwaite PH, Robertson C, Andrews N. Statistical methods for

1247 the prospective detection of infectious disease outbreaks: a review. Journal of the Royal

1248 Statistical Society Series a-Statistics in Society. 2012;175:49-82.

1249 68. Benneyan J, Lloyd R, Plsek P. Statistical process control as a tool for research and

1250 healthcare improvement. Qual Saf Health Care. 2003;12(6):458-64.

1251 69. NSSP Community of Practice 2020 [Available from: https://www.cste.org/page/nsspcop.

1252 70. Surveillance UCDoHIa. National Syndromic Surveillance Program Update - December

2019 | CDC 2019 [updated December 12, 2019. Available from:

1254 https://www.cdc.gov/nssp/news.html.

1255 71. Burkom H. Evolution of Public Health Surveillance: Status and Recommendations.

1256 American Journal of Public Health. 2017.

1257 72. Alemi F, Atherton MJ, Pattie DC, Torii M. Continuously rethinking the definition of

1258 influenza for surveillance systems: a Dependent Bayesian Expert System. Med Decis

1259 Making. 2013;33(6):860-8.

1260 73. Burkom HS, Ramac-Thomas L, Babin S, Holtry R, Mnatsakanyan Z, Yund C. An integrated 1261 approach for fusion of environmental and human health data for disease surveillance. Stat

1262 Med. 2011;30(5):470-9. doi: 10.1002/sim.3976. Epub 2011 Feb 3.

1263 74. Burkom H, Elbert Y, Ramac-Thomas L, Cuellar C. Validation of Analytic Methods for

1264 Combining Evidence Sources in Biosurveillance. Online Journal of Public Health

1265 Informatics. 2014;6(1). 
medRxiv preprint doi: https://doi.org/10.1101/2020.08.14.20175398; this version posted August 17, 2020. The copyright holder for this preprint (which was not certified by peer review) is the author/funder, who has granted medRxiv a license to display the preprint in perpetuity. It is made available under a CC-BY-NC-ND 4.0 International license.

1266 75. Lake IR, Colon-Gonzalez FJ, Barker GC, Morbey RA, Smith GE, Elliot AJ. Machine

1267 learning to refine decision making within a syndromic surveillance service. BMC Public

$1268 \quad$ Health. 2019;19(1):559. 
Message Area

Query

([SYNDROME-"Fever] AND [O-IEFCCMPLAINTS-"“chill"*])

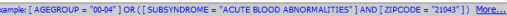

\section{Query Builder}

AND OR ( ) Add Exoression Undo Last Change

\section{Variable Tip}

ZIPCCDE RACEASIANPER CENTAGE

ZIPCODE-RACEELACKORAFRICANAMERICANFERCENTAGE

ZIPCCDE RACEHAWAIIANORPACIFICISLANDER.PERCEINTAGE

ZIPCODE RACEOTHERPERCENTAGE

ZIPCCDE-RACEW-ITEPERIFNTAGE

ZIPCCOEFR.EETEXT

PRIVATE SAVED EXFRESSIONS

RLELIC SAVED EXPRESGIONS

ADMINISTRATOR SAVED EXFRESSTONS

\section{Values}

fiever dills [SYNDROME-"Fever] AND [O-IEFCOMPLAINTS-"zdill*']

Operator

(1)

fever dills

\section{Validate Query Sove Private Expression Sove Public Expression dear Query}




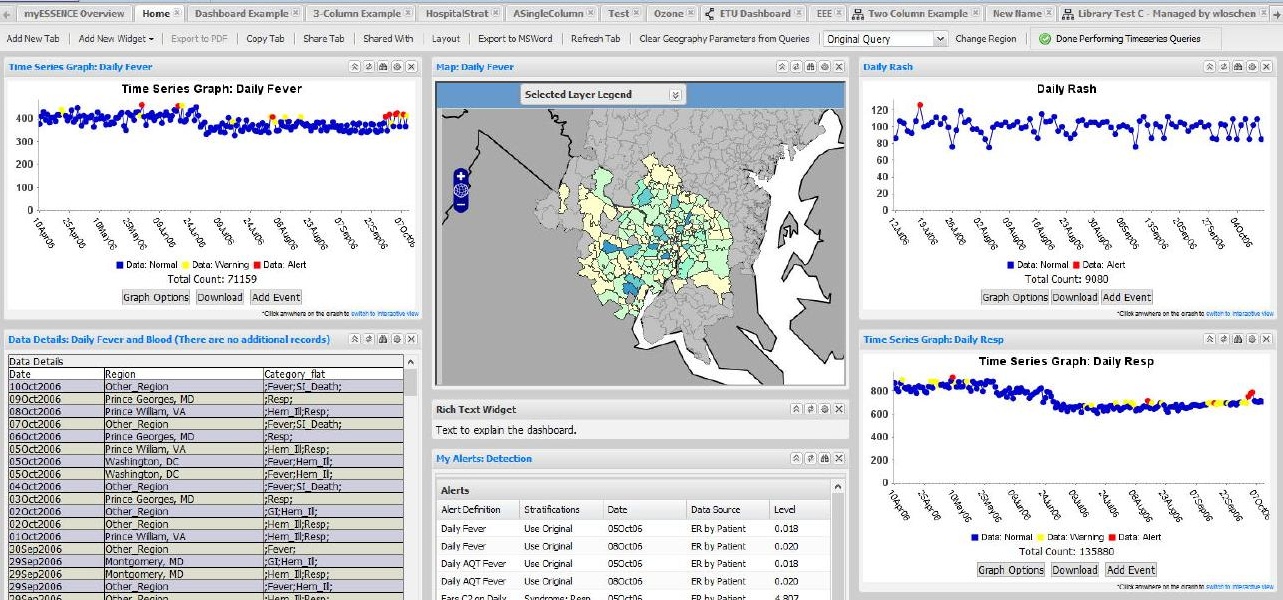




\section{Edit myAlert}

Name of myAlert:

Quer:

Enabled:

myalert being coeated for:

Stratifications:

$\nabla]$ Detector:

Threshoid:

$\square$ Mrimum Count:

प alerts in the past doys

\section{Daly Fever}

Daily Fever

I
Records of Interest $[\nabla]$ Detection

Use Original
Region
Faclity
Faclity Location
Zucode
Regression/EWMA 1.2
0.05

$\square$ consecutive alerts 


\section{ChiefComplaints}

Available Query Fields

$\exists G E R$ Data by Patient Location 콜 MyFilters

白 G Gsou aphy System

$$
\text { 콜egion }
$$

国 Zipcode Free Text

\section{E Facity}

크 Facity Location

Zipcods

日 Medical Grouping System

콕 ChifficomplaintSubsyndrcmes

- 3 Syndrome

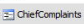

\section{큼 Group}

E ODC ILI Reporting Age Group

\begin{abstract}
프 NOHS Age Group
\end{abstract}
=्ञ Ten Year Age Grow

$<$

Sorts/Fitters/Processing (Beta)
신

$\wedge^{\wedge}$ fever ${ }^{\wedge}$, and, ^ chills

Select Help Query Bulder

Also apply the search strino to:

Discharge Dsoosition Text

Discharge Dagnosis

$\mathrm{CC}$ and $\mathrm{DD}$

Syndrome Free Text

SubSyndrome Free Text

Chief Complant ong Free Text

Clinical Impression

Select Help

\section{Selected Query Fields}

Geography System

$$
\text { Region }
$$

Medical Grouping System

ESSENCESyndromes 


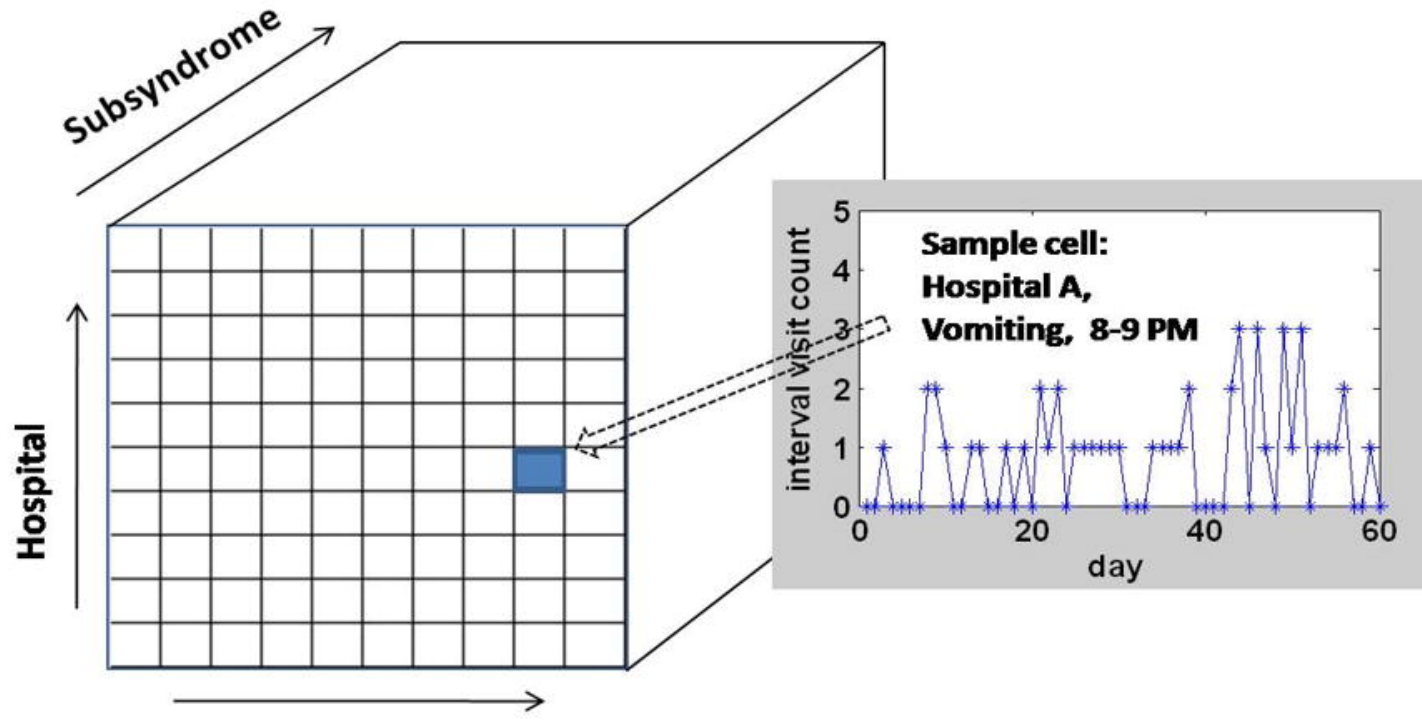

Time of day (hour/half-hour interval) 